\title{
Affiliation of local audit firms with Big4 auditors and capital structure: Evidence from Indonesia
}

\begin{tabular}{|r|l|}
\hline Journal: & Managerial Auditing Journal \\
\hline Manuscript ID & MAJ-05-2019-2291.R1 \\
\hline Manuscript Type: & Research Paper \\
\hline Keywords: & emerging markets, Big4 audit firms, capital structure \\
\hline \multicolumn{2}{|l}{} \\
\end{tabular}

\section{SCHOLARONE ${ }^{\text {M }}$ \\ Manuscripts}




\title{
Affiliation of local audit firms with Big4 auditors and capital structure: Evidence from Indonesia
}

\begin{abstract}
Purpose - This paper investigates whether the choice for a Big4-affiliated local audit firm affects the capital structure of listed companies in Indonesia, a fast-growing emerging country that is characterized by high information asymmetry and low litigation risk. A unique characteristic of the Indonesian audit environment is that Big4 auditors can only enter the market indirectly through affiliation with a local audit firm.
\end{abstract}

Design/methodology/approach - A sample of Indonesian listed companies between 2008 and 2015 is used to investigate this relation using OLS. To address the concern that the choice for Big4-affiliated auditors might reflect client characteristics, we also perform OLS on a matched sample, using both propensity-score and entropy-balance matching.

Findings - Across all three samples, we document that companies audited by a Big4-affiliated local audit firm display lower debt ratios. We find no such effect for affiliation with second-tier audit firms. Surprisingly, we find that the negative effect of Big4 affiliation is increasing in client size.

Research limitations/implications - This study provides evidence of the consequences of hiring Big4 auditors on the perceived information asymmetry by financial markets under extreme conditions: in an environment characterized by low litigation risk and where Big4 auditors can operate only indirectly through affiliation.

Practical implications - The results of this study are of interest to policy makers, managers and financial stakeholders in emerging countries where external financing is important yet difficult to obtain because of severe information asymmetry. Hiring a Big4 auditor - even only through affiliation, might reduce perceived information asymmetry and increase the access to external equity financing.

Originality/Value - To the best of our knowledge, this study is the first to provide evidence of the effect of Big4 auditors on their clients' capital structure when they can operate only indirectly through affiliation with a local auditor.

Keywords emerging markets, capital structure, Big4 audit firm

Paper type Research Paper 


\section{Introduction}

This paper investigates whether the choice for a Big4-affiliated local audit firm affects the capital structure of listed companies in Indonesia. The pecking order theory argues that because of information asymmetry, companies will be financed using internal financing first, and when external financing is needed, debt financing will be preferred over equity financing (Petacchi, 2015; Bharath et al., 2009; Myers and Majluf, 1984). Previous literature has shown that one of the mechanisms to reduce information asymmetry is the appointment of high quality, most often Big4, audit firms, as these firms are expected to increase the credibility of the financial statements (Jensen and Meckling, 1976; Watts and Zimmerman, 1983; Becker et al., 1998; Choi and Wong, 2007; Fan and Wong, 2005). Therefore, one could expect that auditor choice affects the relative attractiveness of debt as a financing means and influences the debt-equity mix (Chang et al., 2009). The basic intuition is the following: Given that debt offers more protection than equity to the providers of finance, debt is - compared to equity - less sensitive to problems of information asymmetry. Accordingly, one might expect that hiring a Big4 auditor lowers, through its effect on the perceived information asymmetry, the optimal debt ratio.

A previous study has already provided evidence consistent with this idea (Chang et al., 2009). However, this study was conducted in the U.S. While some of the capital structure theories tested in developed markets are transferable to emerging countries, specific institutional features which characterize emerging countries might call for country-specific evidence (Booth et al., 2001). For instance, one argument to expect higher quality from Big4 auditors relies on the higher risks and costs of litigation facing Big4 audit firms (Dye, 1993; Deangelo, 1981). The question whether this theory also holds in an environment of low litigation, which characterizes most emerging countries, is an empirical matter. To the best of our knowledge, except for Detthamrong et al. (2017), there exist no studies that have empirically investigated the relation between auditor choice and capital structure in an emerging country.

From a pragmatic point of view, the issue of information asymmetry, its effect on the finance structure and the role of auditors therein is especially pertinent for emerging countries as especially these countries suffer a reputation of low transparency and inferior disclosure quality (Fan and Wong, 2002; Claessens and Yurtoglu, 2013) coupled with weak investor protection (Leuz et al., 2003). Moreover, unlike most companies from developed countries which have diffuse ownership, companies in emerging countries are characterized by highly concentrated family ownership (Claessens and Yurtoglu, 2013; Claessens et al., 2000) and involvement of family members in the top management (Fan et al., 2011; Prabowo and Simpson, 2011). Given that companies in emerging countries are relatively more dependent on external funds to boost their economic growth (Atkins \& Glen, 1992), the relatively high information asymmetry is a restriction with potentially material negative consequences for the development of companies and the country as a whole. 
Indonesia is a setting which is especially interesting to investigate this question as foreign (Big4 or other) auditors are only allowed to operate in Indonesia indirectly through affiliation with a local auditor. Hence, documentation of a negative relation between Big4 involvement and leverage in such a setting would provide relatively strong evidence of the effect of Big4 auditors on perceived information asymmetry.

We test our hypothesis on a sample of Indonesian listed firms between 2008 and 2015. We regress the debt ratio on a dummy variable indicating whether or not the audit is performed by a Big4affiliated local audit firm and a set of control variables. We are conscious about potential endogeneity concerns arising from self-selection. Prior research has argued not only that the auditor choice by companies is non-random and related to company-characteristics but also that audit firms themselves decide whether they will accept or reject clients (Eshleman and Guo, 2014). Big4 audit firms might avoid low-quality or high-risk clients (DeFond et al., 2017; Johnstone, 2000; Johnstone and Bedard, 2004) to minimize litigation risk. Accordingly, potential clients with significant risk of financial distress as a result of high leverage might be avoided by Big4 audit firms. The endogenous nature of auditor choice may render standard linear regression on an unmatched sample inappropriate resulting in biased coefficient estimates. To address this concern, we also perform OLS on a propensity-score matched sample and on an entropy-balance matched sample. Across these three sample compositions, we find evidence of a negative relation between affiliation with a Big4 auditor and leverage.

Next, we also were interested to investigate whether affiliation with a second-tier auditor would produce a similar effect. The growth of second-tier firms and the emergence of 'second-tier' as a brand name suggests that second-tier audit firms also face reputation and litigation concerns, which would reduce the differences in their incentive system compared with that of the Big4 audit firms. To investigate this, we re-code our dummy variable so that it now indicates both affiliation with either Big4 or second-tier audit firm. For all sample compositions (unmatched, PSM and entropy-balance), we find that, although still negative, the effect on leverage is smaller when second-tier firms and Big4 firms are considered as one class. Subsequently, we delete all firm-year observations with Big4 affiliations. In the remaining sample, we create a new dummy variable indicating affiliation with a second-tier audit firm. Across the three sampling methods (unmatched, PSM and entropy-balanced) we find that the effect of affiliation with second-tier auditors is, with a few exceptions, not significant.

Finally, we wanted to investigate whether the effect of Big4 affiliation would differ according to the size of the client. Information asymmetry is expected to be higher for small companies (Bhushan, 1989; Collins, Kothari \& Rayburn, 1987) as these firms experience less extensive analyst following (Barth, Kasznik \& McNichols, 2001) and media coverage (Fang \& Peress, 2009). Hence, we expect there to be less opportunity for Big4 auditors to further mitigate information asymmetry for large companies. We include an interaction effect between Big4 affiliation and size to investigate this 
hypothesis. Surprisingly, we find that the negative effect of Big4 affiliation increases with size. A possible explanation is that increased analyst activity and media attention which surrounds large companies also makes the perceived higher financial reporting quality from Big4 affiliation more salient in the financial markets.

This study contributes to the empirical literature on the link between information asymmetry and companies' capital structure in various ways. First, it contributes by investigating the effect of the appointment of a Big4 audit firm on capital structure in an emerging country where litigation risk is low. As such it complements prior evidence from the U.S. setting where there is a substantial risk of litigation (Chang et al. 2009) and indicates that litigation risk is not a necessary condition for a reduction in perceived information asymmetry by appointing a Big4 auditor. Second, the study examines this impact in an emerging country where Big4 firms can only enter the market through affiliation with a local audit firm. Evidence on the effects of Big4 adoption in such environments is scarce. A notable exception is Houque et al. (2017) who examine the impact of the affiliation of local Indian audit firms with one of the Big4 on the cost of equity capital of the clients. We add to this study by examining the impact of Big4 affiliation on client debt ratios. By providing evidence that hiring a high-quality auditor is negatively associated with financial leverage in Indonesia we also contribute to an emerging literature on the impact of Big4 audits on the financing of firms in non-US markets in general (Houque et al. 2017, Okere et al. 2018, Detthamrong et al. 2017).

For emerging countries, where external capital is important but obtaining finance is often hindered by severe information asymmetry, our result that the choice of a reputable audit firm is associated with a lower debt ratio might be of interest to policy makers, as well as managers and financial stakeholders. Concretely, for policy makers the results imply that taking action to ease the entrance of Big4 firms in the Indonesian audit market can support firms' access to external funds and as such economic growth. An implication for managers is to seriously consider incurring the cost of appointing of a Big4-affilated auditor as this leads to benefits in the form of enhanced access to external funds to finance their growth.

Indonesia provides a pertinent context for research on the role of Big4 audit firms in the access to external finance. First of all, Indonesia is one of the emerging countries with the highest economic growth. For instance, during the period 2004 to 2014, the annual growth rate of real GDP was about 5.9\% (Oliver Wyman and Mandiri Institute, 2015). To maintain this growth, the Indonesian companies rely heavily on external financing, hence the access to external financing instruments is a matter of material importance. Secondly, similar to other emerging countries, in Indonesia, severe information asymmetries often hamper the access to finance. The major causes of information asymmetry in Indonesia - and also other East Asian countries - are highly concentrated ownership (Claessens et al., 2000; Fan and Wong, 2002) and involvement of family members in top management (Prabowo and 
Simpson, 2011). Tabalujan (2002) shows for Indonesian companies, that family members often occupy key management functions or sit on the board of directors leading to even more severe information asymmetry between a company and its external financial stakeholders (Fan and Wong, 2002). In addition, Indonesia suffers a reputation of low transparency and disclosure quality (Fan and Wong, 2002; Claessens and Yurtoglu, 2013) and of weak investor protection (Leuz et al., 2003). In such an environment the potential impact of auditor choice on financing access and hence economic growth might be economically very important and worthwhile of study. Thirdly, to the best of our knowledge, Indonesia is one of the few countries where foreign (Big4, second-tier or other) auditors are only allowed to offer their services indirectly by affiliation with a local audit firm. The fact that the local auditor still has to be involved and the international auditor can only have an indirect effect - through its cooperation with the local auditor - makes any findings that Big4 auditors have an effect on the leverage ratio, stronger than in countries where Big4 auditors can operate directly.

The remainder of this paper is organized as follows. First, we describe the Indonesian background including its accounting and audit environment. Then, we provide a literature review and develop our hypothesis. Next, we describe our research design and data collection procedure. Afterwards, we present our empirical findings and conduct some additional analyses. The last section concludes.

\section{Institutional background}

The financial environment

Indonesia is the largest economy in South-east Asia, represents almost 40 percent of the region's economic output. It is the world's fourth most populous nation, the world's $10^{\text {th }}$ largest economy in terms of purchasing power parity and a member of the G-20 (The World Bank, 2019).

Nonetheless, the Indonesian capital markets are relatively under-developed (Oliver Wyman and Mandiri Institute, 2015). In 2014, the market capitalization of listed domestic companies in percentage of GDP was 47\% (The World Bank, 2016) and the number of listed companies is 506 (Indonesia Stock Exchange, 2016). The public debt market in Indonesia is dominated by government bonds, corporate bonds representing only $30 \%$ of the funds raised (IDX and IBPA, 2014). Bond market liquidity is generally quite low (Oliver Wyman and Mandiri Institute, 2015). The number of companies with listed corporate bonds in 2014 is 102 (Indonesia Stock Exchange, 2016). Debt financing, through bank loans, is an important financial source (Oliver Wyman and Mandiri Institute, 2015). In 2014, bank loan funding amounted to about $58 \%$ of total corporate funding in Indonesia (Oliver Wyman and Mandiri Institute, 2015). For our sample of listed firms, the average total debt ratio is about $32 \%$ using the market value of equity and $37 \%$ using the book value of equity while the average long-term debt ratio is $23 \%$ and $25.5 \%$ respectively. 


\section{The Indonesian accounting and audit environment}

The Limited Liability Company Law No. 40 of 2007 requires corporate entities to prepare financial statements in accordance with the Indonesian financial accounting standards (SAKSs) issued by the Indonesian Financial Accounting Standard Board (DSAK) of the Institute of Indonesian Chartered Accountants (IAI) (IFAC, 2016). The IAI is responsible for the regulation of the professional accountants, including setting accounting standards in the private sector, administering the Chartered Accountant Indonesia exam, providing continuing professional education, establishing a code of ethics, adopting professional standards and maintaining a disciplinary system for its members. In 2012, as part of the ongoing convergence process, the DSAK aligned SAKs with the IASs and IFRSs as they existed in 2009. By January 1, 2015, at the end of a second phase of the convergence process, SAKs were substantially aligned with IASs and IFRSs as they existed in 2014.

The financial reports of publicly listed companies should be audited. The Indonesian Institute of Public Accountants or IAPI is legally empowered to set auditing standards (SPAPs) for the public accountancy profession. In 2012, International Standards on Auditing (ISAs) (2010) were adopted. These standards are effective for listed companies for audits of financial statements for periods beginnings on or after January, 2013 (IFAC, 2016).

Foreign audit firms can only enter the Indonesian audit market through partnering with a local audit firm. According to Indonesian regulation, an international audit firm partnering with a local firm should provide training programs, impose standards on quality control and perform periodic quality controls. Kartikahadi (2010) describes that the Big4 audit firms use tight selection and evaluation procedures in choosing their local partners. The evaluation of a local business partner covers factors such as the firm's compliance with professional standards, its business plan, the completeness of the professional services offered, the quantity and quality of the professional staff and the organization structure and the available infrastructure. The affiliating international auditor is required to organize consulting workshops, annual meetings and quality reviews for its local partners.

There are several indicators suggesting that there are serious quality issues within the local Indonesian accounting and audit context (Dunakhir, 2016). With few exceptions, most accounting firms in Indonesia are relatively small. Many firms are audited by capacity-constrained accounting firms (The World Bank, 2010a). The local accounting firms, due to lack of adequate resources, face challenges in providing high-quality auditing services for entities with complex business transactions. Anecdotal evidence from interviews with practicing auditors revealed high levels of compliance gaps with respect to audit planning, documentation, related party investigation and fraud detection

Furthermore, in many emerging markets, regulations are not fully enforced (Ball, 2001; Chan and Hameed, 2006). This is also the case in the Indonesian audit environment. Cases where companies, shareholders or third parties sue public accounting firms are very rare. This is assumed to be the result 
of costly and time consuming court processes, lack of experienced judges and laws and regulations that are perceived to be ambiguous (The World Bank, 2010b). Brown et al. (2014) classified countries based on the quality of the auditors' working environment and the degree of accounting enforcement and ranked Indonesia as $46^{\text {th }}$ of 51 countries, indicating low quality.

\section{Prior literature review and hypothesis development}

Central in the pecking order theory is that information asymmetry drives a hierarchical financing strategy: a company will prefer internal financing, and when external financing is needed, debt financing is preferred over equity financing (Myers and Majluf, 1984). Debt is less informationsensitive because by issuing debt, companies offer pre-commitment that serves as a protective mechanism for the holders such as interest and principal payments, debt covenants and the possibility to force liquidation (Grossman and Hart, 1982). Equity would be the finance source of last resort as it is the most sensitive to information asymmetry. Consequently, firms characterized by higher information asymmetry would have relatively more debt over equity financing, i.e. display higher leverage ratios. There exists empirical evidence from developed markets, mainly from the US, consistent with this idea (Bharath et al., 2009; Petacchi, 2015).

One particular mechanism to reduce information asymmetry is the appointment of a high quality external auditor. Previous research has argued (Jensen and Meckling, 1976) and documented (Watts and Zimmerman, 1983) that an external audit can enhance the credibility of financial statements thereby mitigating information asymmetry problems. It is further argued that Big4 audit firms provide external audit services of higher quality (Becker et al., 1998; Choi and Wong, 2007; Fan and Wong, 2005 ) in order to maintain their valuable reputation (Deangelo, 1981) and/or in order to avoid expensive litigation resulting from them having "deeper pockets" (Dye, 1993). Companies hiring Big4 audit firms would therefore be relatively more inclined to finance with equity over debt, and would thus display lower leverage ratios. Chang et al. (2009) provided evidence of a negative relationship between audit quality and the debt ratio for the US setting.

Previous research has shown that in emerging countries external financing is relatively more important than internal financing (Atkins and Glen, 1992), yet exactly for these countries, much less is known about the effect of information asymmetry on firms' capital structure than for developed countries. Moreover, Booth et al. (2001) find that, although some of the insights in capital structure theory in developed countries can be applied in emerging countries, there are differences across countries which require country-specific testing of theories. Therefore, we find it worthwhile to empirically test the following hypothesis in the context of an emerging country like Indonesia:

H: Companies audited by Big4 audit firms display lower leverage ratios than those audited by nonBig4 audit firms 


\section{Research design}

To test our hypothesis, we regress companies' leverage on a dummy indicating whether a company's local auditor was affiliated with a Big4 auditor or not together with a set of control variables.

Our basic regression looks as follows:

$$
\begin{aligned}
\mathrm{DR}_{\mathrm{j}, t+1}= & \beta_{0}+\beta_{1} * \mathrm{BIG}_{\mathrm{j}, \mathrm{t}}+\beta_{2} * \mathrm{SIZE}_{\mathrm{j}, \mathrm{t}}+\beta_{3} * \mathrm{ROA}_{\mathrm{j}, \mathrm{t}}+\beta_{4} * \operatorname{INDLEV}_{\mathrm{j}, \mathrm{t}}+\beta_{5} * \mathrm{MTB}_{\mathrm{j}, \mathrm{t}} \\
& +\beta_{6} * \mathrm{RET}_{\mathrm{j}, \mathrm{t}}+\beta_{7} * \mathrm{PPE}_{\mathrm{j}, \mathrm{t}}+\beta_{8} * \operatorname{DEBTAX}_{\mathrm{j}, \mathrm{t}}+\beta_{9} * \operatorname{NDEBTAX}_{\mathrm{j}, \mathrm{t}}+\beta_{10} \\
& * \mathrm{SDROA}_{\mathrm{j}, \mathrm{t}}+\varepsilon_{\mathrm{j}, \mathrm{t}}
\end{aligned}
$$

The dependent variable is the debt ratio DR. Prior studies suggest different operational measures. According to Rajan and Zingales (1995), the effects of past financing decisions are best represented by the ratio of total long term debt to capital, which includes total long term debt in the numerator. A number of capital structure studies in developing countries (Booth et al., 2001; DemirgucKunt and Maksimovic, 1999) however has shown that short term debt in developing countries is relatively more significant compared to developed countries. Accordingly, we use a second debt ratio, i.e. the total debt to capital ratio, which includes both short- and long-term debt in the numerator. To examine the robustness of the results, each debt ratio is calculated using as denominator either the sum of the book values of debt and equity or the sum of the market value of equity and the book value of debt. Hence, we calculate four different debt ratio measures. LTDMEQ is the long term debt ratio using the market value of equity capital and the book value of debt in the denominator, while LTDEQ is defined as the long term debt ratio using the book value of equity and debt capital in the denominator. The total debt ratios, TDMEQ and TDEQ, are defined accordingly. As in prior literature (e.g. Gao \& Zhu, 2015) we use one-year-ahead debt ratio measures for the dependent variable.

Our variable of interest is BIG4, a dummy variable indicating whether the local auditor was affiliated with a Big4 firm or not. The control variables are consistent with prior empirical literature investigating the debt ratio (Chen et al., 2016; Frank and Goyal, 2009; Rajan and Zingales, 1995; Booth et al., 2001). Regarding SIZE, here measured as the natural logarithm of total assets, the trade-off theory predicts that large firms are generally more diversified and have a better reputation, leading to a lower risk of default. Therefore, larger firms tend to have higher leverage (Frank and Goyal, 2009; Fama and French, 2002). The next variable, ROA, defined as net income before extraordinary items scaled over assets, is a measure of profitability. According to the pecking order theory firms prefer internal over external financing (Myers and Majluf, 1984). An alternative theory, the dynamic trade-off theory, states that firms accumulate profits passively (Fischer et al., 1989). Both theories predict a negative relation between profitability and leverage. INDLEV is the industry median of the dependent variable. Hovakimian et al. (2001) empirically showed that firms adjust their debt ratio toward the industry 
average. MTB or the market-to-book ratio proxies for growth and investment opportunities. Following (Rajan and Zingales, 1995), it is calculated as the sum of the book value of debt and the market value of equity, scaled by the book value of total assets. The relation between growth opportunities and leverage is ambiguous (Frank and Goyal, 2009). The trade-off theory predicts that growth reduces leverage since firms with more growth opportunities will rely more on shareholders' investment (Frank and Goyal, 2009). In contrast, the pecking order theory implies a positive relationship between growth and leverage. Higher growth firms need more funds to finance their investments and therefore tend to accumulate more debt (Frank and Goyal, 2009). Following Frank and Goyal (2009), we also include the stock market return over the last year (RET). The market timing theory predicts a negative relation since higher market returns indicate preferable circumstances to issue equity. PPE is measured as property, plant and equipment divided by total assets. Frank and Goyal (2009) suggest a positive relation between the proportion of tangible assets and leverage since this type of assets is easier to value by outsiders which lowers expected distress costs. Furthermore, the tangible assets can serve as collateral (Chen et al., 2016). The variable DEBTAX is calculated as current income tax divided by pre-tax income and is a proxy for the marginal tax rate. Firms have more incentives to increase debt if the marginal tax rate is higher because of the higher tax deductibility of interest expense (Chen et al., 2016; Frank and Goyal, 2009). NDEBTAX is calculated by depreciation expense divided by total assets and is a proxy for non-debt tax shields, which are a substitute for tax deductibles from debt (Deangelo and Masulis, 1980). Firms with high depreciation have less interest in other tax deductibles like interest payments from debt, so a negative relation between NDEBTAX and the debt ratio is expected (Deangelo and Masulis, 1980). However, Bradley et al. (1984) argue that there is a positive association between depreciation expense and leverage since high depreciation means high tangible assets that allow the companies to borrow at lower interest rates if the tangible assets are used to secure the debt. Therefore, there is an ambiguous relationship between NDEBTAX and the debt ratio. Finally, the variable SDROA is defined as the standard deviation of ROA over the previous three years and is a proxy for business risk. It is expected to have a negative relation with leverage (Booth et al., 2001).

\section{[Insert Table 1 about here]}

When estimating our basic regression with ordinary least squares (OLS), potential endogeneity concerns arise because it can be argued that auditor choice by the company is not random but related to certain company characteristics which are also related to the debt ratio. Furthermore, the audit firms themselves decide whether or not they will accept or reject clients (Eshleman and Guo, 2014). Big4 firms may avoid low-quality and risky clients (DeFond et al., 2017) to minimize litigation risk (Johnstone and Bedard, 2004; Johnstone, 2000). According to this reasoning, clients with high risk of financial distress due to a high level of indebtedness may find it more difficult to attract a Big4 auditor. 
Accordingly, applying OLS to an unbalanced sample of Big4 and non-Big4 clients might result in a biased estimate of the treatment effect of BIG4, whereby the estimated coefficient also reflects client characteristics. To address this concern, we try two alternatives. First, we compose a propensity-score matched control sample. The technique of propensity score matching (PSM) pairs observations based on the probability of undergoing a treatment, which in our case is the probability of using a Big4 auditor. The matching models generate samples in which the clients of Big4 and non-Big4 auditors are similar, providing a setting which allows to estimate the effects of Big4 auditor choice free from bias from related client characteristics (Shipman, Swanquist and Whited, 2016; Wilde, 2017). Armstrong et al. (2010) argue that propensity score matching on both the determinants of the treatment (i.e. Big4 affiliation) and the determinants of the outcome (i.e. the debt ratio) relaxes the assumption of a constant functional relationship between the control variables and the outcome of interest. Accordingly, we include both determinants of the debt ratio and of Big4 in the matching model used to select control firms. Our explanatory variables for Big4 are based on prior literature (Chaney et al., 2004; Choi and Wong, 2007; Fan and Wong, 2005; Guedhami et al., 2014, Suryanto et al. 2017). First, to take into account the effect of foreign ownership, we create a dummy variable FOREIGN, taking the value of 1 if the largest shareholder is from a foreign country and zero otherwise. Investors from foreign countries tend to demand higher quality financial reporting (He et al., 2014). Firms are expected to respond to this demand by appointing a Big4 audit firm. The variables OWN, CROSS, and STATE are intended to capture the influence of agency conflicts on audit demand. OWN stands for concentrated ownership and is calculated as the percentage of closely held shares as defined in Worldscope. More in particular this is the percentage of shares held by cross-holdings, corporations, holdings, governments, employees and individual insiders. Highly concentrated ownership creates agency conflicts between controlling and minority shareholders (Fan and Wong, 2005). Big4 audit firms can serve as a signal to mitigate agency conflicts (Choi and Wong, 2007). Fan and Wong (2005) document that firms with highly concentrated ownership are more likely to choose a Big4 audit firm. Therefore, we expect a positive coefficient on this variable. CROSS is a dummy variable indicating that a company is cross-listed abroad. Previous literature (Fan and Wong, 2005; Guedhami et al., 2014) suggests that cross-listing may affect a company's choice for a Big4 audit firm. Again, we expect a positive sign on this coefficient. STATE is a dummy variable indicating that a company is state-owned. Chen et al. (2011) argue that state-owned companies are less likely to choose high quality auditors since there is less demand for high-quality financial reporting in those companies. Accordingly, we expect a negative sign for this coefficient.

We further include SIZE, ATURN and CURR. SIZE is measured as the natural logarithm of total assets while ATURN is calculated as the proportion of total sales to total assets. SIZE and ATURN proxy for the size and the level of economic activity of the company respectively and are expected to indicate the level of auditors' effort to achieve a sufficient level of assurance (Simunic and Stein, 1996; 
Francis et al., 1999; Choi and Wong, 2007; Piot, 2001). Following Chaney et al. (2004), we also include the ratio of current asset to total assets (CURR) in the regression due to the complexities of inventories and receivables which may require specific audit procedures. We expect a positive coefficient on all three variables.

To control for financial risk, we use LEV, LOSS and ROA. LEV is measured as long-term debt scaled by total assets. LOSS is a dummy variable indicating the occurrence of negative net income before extraordinary items in the previous year. ROA, return on assets of the year, is calculated as net income before extraordinary items scaled by total assets. LEV and LOSS are associated with the probability of a client's financial distress which is related to audit risk (Choi and Wong, 2007). Hence, a negative relation is expected. However, LEV also captures potential agency conflicts. Chaney et al. (2004) argue that highly leveraged firms may prefer to hire high quality auditors to reduce agency costs. Therefore, the direction of LEV is unclear. The variable ROA captures profitability. Previous studies (Chaney et al., 2004; Guedhami and Pittman, 2011; Fan et al., 2011) suggest that auditor choice might be influenced by a firm's profitability. We expect a positive coefficient of ROA since more profitable firms tend to have less audit risk.

Notwithstanding the benefits of PSM, this matching technique is not without its disadvantages (Lawrence, Minutti-Mezza and Zhang, 2011). First of all, PSM eliminates observations that lack counterfactuals. The loss of a substantial portion of the sample may limit the ability to make valid generalizations. Secondly, PSM requires several design choices like caliper distance and whether to match with or without replacement. Alternative choices are often equally defensible and may impact sample composition and hence the estimation of the treatment effect.

Given these weaknesses, we also perform OLS on an entropy-balanced sample. Entropy balancing is a relatively new matching technique that weighs control sample units to achieve covariate balance between Big4 and non-Big4 groups along the first, second and third moments of the control variable distributions without requiring design choices that can affect the composition of the control sample (Wilde, 2017). To achieve this balance, rather than PSM, which eliminates observations without counterfactuals, i.e. gives these a weight of zero, entropy balancing weighs observations smoothly. This way, entropy-balancing allows the researcher to use the complete sample for regression analysis.

\section{Data Collection and Sampling Procedure}

All financial data were retrieved from Worldscope. Since Worldscope only provides data on the auditor of the latest available year, we hand-collected the data on the auditors over the years of the study from the Indonesian Capital Market Directory (ICMD) and the companies' audit reports. The audit reports, included in the companies' financial statements that were retrieved from the website from Indonesian Stock Exchange, state both the name of the local auditor and the international partner (if 
any). By regulation, foreign audit firms can only enter the Indonesian audit market through cooperation with a local audit firm. Additionally, one foreign audit firm can only cooperate with one local audit firm. We identify local audit firms that affiliate with Big4 namely (1) Purwantono, Suherman \& Surja that affiliate with Ernst \& Young; (2) Siddharta, Widjaja \& partner with KPMG; (3) Satrio, Bing, Eny $\&$ partners with Deloitte and (4) Tanudiredja, Wibisana, Rintis that partner with PwC. Following Hogan and Martin (2009) in defining second-tier audit firms we identify Grant Thornton, Crowe, and BDO Seidman as international second-tier audit firms in our sample. The local audit firms that affiliates with those are (1) Gani, Sigiro \& Handayani; (2) Kosasih, Nurdiyaman, Mulyadi, Tjahjo \& partners and Tanubrata, Sutanto, Fahmi, Bambang \& partners. Other local audit firms that affiliate with non-Big4 and non-second-tier and those that are not affiliated with foreign audit firms are classified as "others". Ownership data were hand-collected from the ICMD and company financial statements.

\section{[Insert Table 2 about here]}

Table 2 summarizes our sample selection procedure. We began with the set of non-financial Indonesian listed companies that existed between 2008 and 2015. Initially, our sample contained 2,573 company-year observations. From the initial sample, we excluded companies that experienced an asset growth rate of more than 100 percent in any year (64 company-years), as the latter is an indication of significant restructuring activities (Duchin et al., 2010). Further, to guarantee independent observations, we excluded subsidiary companies when the parent company was also included in our sample (138 company-years). Finally, we dropped 394 company-years for which there were missing values. Our final sample consisted of 1,977 company-years. Table 3 provides a breakdown of the sample by year and industry. Comparing our sample with the initial sample, there appear to be no major problems with respect to over- or underrepresentation of certain years or sectors.

[Insert Table 3 about here]

\section{Empirical results}

Descriptive statistics

Table 4 presents the descriptive statistics. We winsorized all continuous variables at the $1^{\text {st }}$ and $99^{\text {th }}$ percentiles. From panel A, we can see that the averages of LTDMEQ and LTDEQ are $23.3 \%$ and $25.5 \%$ respectively, the means of TDMEQ and TDEQ being $32.1 \%$ and $36.9 \%$. 
[Insert Table 5 about here]

\section{Regression results}

In Table 6, panels $\mathrm{A}, \mathrm{B}$ and $\mathrm{C}$ show the results from our regression analysis on the unmatched, PSM and entropy-balance matched sample respectively. First of all, regarding our control variables, we find the most consistent results for size and profitability. The coefficients of SIZE is significantly positive across all samples and for all leverage measures. This is consistent with the trade-off theory according to which bigger companies have lower default risk due to their better diversification and reputation so that they tend to have higher leverage. The coefficients of ROA are significantly negative at $1 \%$ for all our leverage measures and across all samples. This supports both the pecking order and the dynamic trade-off theory. The coefficients on the industry medians of the dependent variable show that there is positive industry dependence, however not for all samples and not for all measures of leverage. The coefficient for MTB is either negative or insignificant, yielding mild support for the pecking order theory. The coefficient of PPE yields inconsistent results across the different estimations. Surprisingly, if significant, then the coefficient of DEBTAX is negative, which is, inconsistent with the idea of the tax-shield effect from debt. Booth et al. (2001) offer an explanation that the tax rate in the emerging 
countries seems to be a proxy of profitability. More profitable companies have less demand for external financing (Donaldson, 1963; Higgins, 1977). If significant, the coefficient of NDEBTAX is positive which is consistent with the argument by Bradley et al. (1984) that companies that have high depreciation have high tangible assets that allow them to borrow at lower interest rates if the tangible assets are used to secure the debt.

With regard to our variable of interest, BIG4, across all definitions of leverage and across all samples, we find a significant negative effect of being audited by a local auditor which is affiliated with a Big4 audit firm. This effect is also economically significant, i.e. the effect of BIG4 on the debt ratio ranges between -3.1 (Table 6B, second column) and -8.1 (Table 6A, first column) percentage points. This evidence is in line with our hypothesis that Big4 audit firms reduce perceived information asymmetry, even in a country like Indonesia, where risk of litigation is relatively low and where the involvement of the Big4 audit firm is only through affiliation.

[Insert Table 6 about here]

\section{Additional analyses}

Affiliation with Big4 versus second-tier audit firms

We were also interested to find out whether affiliation of a local Indonesian audit firm with a second-tier audit firm also has a (similar) negative effect on leverage. The growth of second-tier firms and the emergence of 'second-tier' as a brand name suggests that second-tier audit firms also face reputation and litigation concerns, which would reduce the differences in their incentive system compared with that of the Big4 audit firms. In the US for instance, regulators have been promoting second-tier firms as a viable alternative to the Big4 firms, based on the belief that they provide similar audit quality. Boone et al. (2010), for a sample of U.S. listed companies, found small differences in actual audit quality between Big4 and second-tier clients. However, the differences in perceived audit quality, as measured by the ex-ante equity risk premia, were still pronounced in favour of Big4 clients. Cassell et al. (2013) found that for a sample of listed US firms that the financial reporting credibility of second-tier audit clients became indistinguishable from that of Big4 clients as the size of second-tier audit firms increased over time. Accordingly, we wanted to investigate for our sample of Indonesian firms whether affiliation with a second-tier auditor also had a negative effect on leverage.

We follow Hogan and Martin (2009) in defining second-tier audit firms and identified Grant Thornton, Crowe and BDO Seidman as international second-tier firms that have affiliations with local Indonesian audit firms. We then employ two research designs to investigate this question.

First, we re-code our dummy variable so that it now indicates both affiliation with either Big4 or second-tier audit firm. The base case then applies to a local auditor with affiliation to an international 
audit firm which is neither a Big4 nor second-tier audit firm or to a local auditor with no affiliation at all. The left side of Table 7 (A, B \& C) shows the results of re-estimating our basic regression where Big4 is defined accordingly (for the unmatched, PSM and entropy-balance matched sample respectively). Although the coefficients of this more encompassing dummy are generally still negative and significant, the absolute value of these coefficients is generally smaller than when the Big4 dummy captured only audits by the Big4-affiliated audit firms in Table 6. So the effect that we find for affiliation is smaller when also affiliations with second-tier firms are considered.

In a second research design to address this question, we delete all firm-year observations with Big4 affiliations. In the ensuing sample, we define a new dummy 2NDTIER, which is coded one when the local auditor was affiliated with a second-tier audit firm and zero in all other cases. The results of estimating our basic regression on this reduced sample with the variable BIG4 replaced by the variable 2NDTIER are shown in the right side of Table 7. Across the three sampling methods (unmatched, PSM and entropy-balanced), we find that the effect of affiliation with second-tier auditors is generally not significant and when significant, the effect is negative as the effect of affiliation with Big4 auditors that we found in Table 6 .

[Insert Table 7 about here]

\section{Interaction between company size and Big4}

We were also interested to investigate whether the effect of BIG4 would differ according to the size of the client. Information asymmetry is expected to be higher in small companies (Bhushan, 1989; Collins, Kothari \& Rayburn, 1987). These firms experience less extensive analyst following (Barth, Kasznik \& McNichols, 2001) and media coverage (Fang $\&$ Peress, 2009). Based on the notion that, for larger companies, the issues of information asymmetry are less severe, we expect there to be less opportunity for Big4 auditors to further mitigate such information asymmetry. Hence, we expect the negative effect of Big4 on leverage to be less outspoken for larger companies. To empirically test this idea, we added an interaction effect to our basic regression. More in particular, our regression looks as follows:

$$
\begin{aligned}
\mathrm{DR}_{\mathrm{j}, t+1} & \\
& =\beta_{0}+\beta_{1} * \mathrm{BIG}_{\mathrm{j}, \mathrm{t}}+\beta_{2} * \operatorname{SIZE}_{\mathrm{j}, \mathrm{t}}+\beta_{3} * \mathrm{BIG}_{\mathrm{j}, \mathrm{t}} * \operatorname{SIZE}_{\mathrm{j}, \mathrm{t}}+\beta_{4} * \mathrm{ROA}_{\mathrm{j}, \mathrm{t}}+\beta_{5} * \operatorname{INDLEV}_{\mathrm{j}, \mathrm{t}} \\
& +\beta_{6} * \operatorname{MTB}_{\mathrm{j}, \mathrm{t}}+\beta_{7} * \mathrm{RET}_{\mathrm{j}, \mathrm{t}}+\beta_{8} * \mathrm{PPE}_{\mathrm{j}, \mathrm{t}}+\beta_{9} * \operatorname{DEBTAX}_{\mathrm{j}, \mathrm{t}}+\beta_{10} * \operatorname{NDEBTAX}_{\mathrm{j}, \mathrm{t}}+\beta \\
& 11 * \operatorname{SDROA}_{\mathrm{j}, \mathrm{t}}+\varepsilon_{\mathrm{j}, \mathrm{t}}
\end{aligned}
$$

The estimation results for the three samples can be found in Table 8. The effect of BIG4 
on leverage can now no longer be judged on its own as it now depends on SIZE. For example, with the entropy-balance matched sample, the first derivative of leverage (LTDMEQ) with respect to BIG4 equals $0.734-0.036 *$ SIZE. Evaluated at the median SIZE (21.20), the derivative equals $0.734-(0.036 * 21.20)=-0.029$, showing a negative effect of Big4 affiliation on leverage. Surprisingly however, the negative effect increases with SIZE, opposite to what we expected. And this surprising result holds over all leverage measures and across all three samples. One possible explanation is that the increased analyst activity and media attention which surrounds large companies also makes the perceived higher financial reporting quality from Big4 affiliation more salient in the financial markets.

[Insert Table 8 about here]

\section{CONCLUSION}

The purpose of this paper was to investigate whether the appointment of a Big4 audit firm affects the capital structure of Indonesian listed companies. Indonesia is a fast-growing emerging country that is characterized by weak governance, high information asymmetry and low litigation. Prior research suggests that findings from developed countries, mainly the US, need not to hold in a different institutional setting (Booth et al. 2001). Moreover, results of prior research may not hold as in Indonesia foreign (Big4 or other) auditors are only allowed to operate indirectly through affiliation with a local auditor.

We find that listed Indonesian companies audited by local audit firms affiliated with a Big4 audit firm tend to have a lower leverage ratio compared to those audited by non-Big4-affiliated local audit firms. This finding is consistent with the argument that the appointment of a higher quality (Big4) audit firm enhances the perceived credibility of the financial statements, hereby reducing perceived information asymmetry, and indicates that this argument even holds in a low litigation risk setting like Indonesia where Big 4 can only enter the market through affiliation with a local audit firm.

Our results are of interest to policy makers, managers and financial stakeholders in emerging countries where external financing is important (Atkins and Glen 1992) yet difficult to obtain because of severe information asymmetry. Our results suggest that the appointment of a local auditor that is affiliated with an international (especially Big 4) audit firm reduces the perceived information asymmetry hereby helping companies to optimize their capital structure and finance their growth. From a practical point of view, the results suggest that, in order to support the external financing and growth of firms, policy makers may want to ease the entrance of Big 4 auditors in the Indonesian market. From 
a management perspective, the results indicate that the appointment of a Big4-affiliated auditor provides benefits in term of enhanced access to equity financing to finance their growth.

Notwithstanding that, due to the low litigation risk and the indirect foreign auditor access which characterize Indonesia, our research setting is demanding, and our findings are strong, the extent to which our conclusions transfer to other emerging countries is an open question which can only be answered by future studies in other geographic areas. Already a few related studies in other countries have been performed. For instance, Detthamrong, Chancharat \& Vithessonthi (2017) find for small firms in Thailand, the appointment of a Big4 auditor is negatively associated with firm performance, a finding that - according to the authors - can be explained by the deterrence of earnings management as a consequence of the presence of Big 4 auditors. Another example of a related study is Wong, Firth, and Lo (2018), which focusses on a legal distinction which exists between audit firms in China which affects the legal liability of the audit firm. They find that auditor size is positively related to audit quality, but only when the auditors liability is capped. This positive association disappears for audit firms that are subject to high litigation risk exposures. We hope that future studies will shed further light on the effect of Big4 audit firms in emerging countries and the different institutional characteristics that moderate these effects. 


\section{References}

Armstrong, C. S., Barth, M. E., Jagolinzer, A. D., \& Riedl, E. J. (2010). Market reaction to the adoption of IFRS in Europe. The Accounting Review, 85(1), 31-61.

Atkins, M. \& Glen, J. D. 1992. Comparing corporate capital structures around the globe. The International Executive, 34(5), pp 369 - 387.

Ball, R. 2001. Infrastructure requirements for an economically efficient system of public financial reporting and disclosure. Brooking Papers on Financial Services, 127-182.

Barth, M.E., Kasznik, R. \& McNichols, M.F., 2001, Analyst coverage and intangible assets, Journal of Accounting Research, (39(1), pp. 1-34.

Becker, C. L., DeFond, M., Jiambalvo, J. \& Subramanyam, K. R. 1998. The Effect of Audit Quality on Earnings Management. Contemporary Accounting Research, 15(1), pp 1-24.

Bharath, S. T., Pasquariello, P. \& Wu, G. J. 2009. Does Asymmetric Information Drive Capital Structure Decisions? Review of Financial Studies, 22(8), pp 3211-3243.

Bhushan,R., 1989, Firm characteristics and analyst following Journal of Accounting and Economics, 11(2-3), pp. 255-274.

Boone, J.P., Khurana, I.K. \& Raman, K.K., 2010, Do the Big 4 and the Second-tier firms provide audits of similar quality?, Journal of Accounting and Public Policy, 29(4), pp. 330-352.

Booth, L., Aivazian, V., Demirguc-Kunt, A. \& Maksimovic, V. 2001. Capital structures in developing countries. Journal of Finance, 56(1), pp 87-130.

Bradley, M., Jarrell, G. A. \& Kim, E. H. 1984. On the Existence of an Optimal Capital Structure Theory and Evidence. Journal of Finance, 39(3), pp 857-878.

Brown, P., Preiato, J. \& Tarca, A. 2014. Measuring Country Differences in Enforcement of Accounting Standards: An Audit and Enforcement Proxy. Journal of Business Finance \& Accounting, 41(1-2), pp 1-52.

Cassell, C.A., Giroux, G., Myers, L.A. \& Omer, T., (2013). The emergence of second-tier auditors in the US: Evidence from investor perceptions of financial reporting credibility. Journal of Business Finance \& Accounting, 40(3-4), pp. 350-372.

Chan, K. \& Hameed, A. 2006. Stock price synchronicity and analyst coverage in emerging markets. Journal of Financial Economics, 80(1), pp 115-147.

Chaney, P. K., Jeter, D. C. \& Shivakumar, L. 2004. Self-selection of auditors and audit pricing in private firms. Accounting Review, 79(1), pp 51-72.

Chang, X., Dasgupta, S. \& Hilary, G. 2009. The Effect of Auditor Quality on Financing Decisions. Accounting Review, 84(4), pp 1085-1117.

Chen, H. W., Chen, J. Z., Lobo, G. J. \& Wang, Y. Y. 2011. Effects of Audit Quality on Earnings Management and Cost of Equity Capital: Evidence from China. Contemporary Accounting Research, 28(3), pp 892-+. 
Chen, J. Z., Lim, C. Y. \& Lobo, G. J. 2016. Does the relation between information quality and capiral structure vary with cross-country institutional differences? Journal of International Accounting Research, 15(3), pp 131-156.

Choi, J. H. \& Wong, T. J. 2007. Auditors' governance functions and legal environments: An international investigation. Contemporary Accounting Research, 24(1), pp 13-+.

Claessens, S., Djankov, S. \& Lang, L. H. P. 2000. The separation of ownership and control in East Asian Corporations. Journal of Financial Economics, 58(1-2), pp 81-112.

Claessens, S. \& Yurtoglu, B. B. 2013. Corporate governance in emerging markets: A survey. Emerging Markets Review, 15, pp. 1-33.

Collins, D.W., Kothari, S.P. \& Rayburn, J.D., 1987, Firm size and the information content of prices with respect to earnings. Journal of Accounting and Economics, 9(2), pp. 111-138.

Deangelo, H. \& Masulis, R. W. 1980. Optimal Capital Structure under Corporate and Personal Taxation. Journal of Financial Economics, 8(1), pp 3-29.

Deangelo, L. E. 1981. Auditor size and audit quality. Journal of Accounting \& Economics, 3(3), pp $183-199$.

DeFond, M., Erkens, D. H. \& Zhang, J. Y. 2017. Do Client Characteristics Really Drive the Big N Audit Quality Effect? New Evidence from Propensity Score Matching. Management Science, 63(11), pp 3628-3649.

Demirguc-Kunt, A. \& Maksimovic, V. 1999. Institutions, financial markets, and firm debt maturity. Journal of Financial Economics, 54(3), pp 295-336.

Detthamrong, U., Chancharat, N. \& Vithessonthi, C. 2017. Corporate governance, capital structure and firm performance: Evidence from Thailand, Research in International Business and Finance, 42, pp. 689-709.

Donaldson, G. (1963). Financial goals: Management vs. stockholders. Harvard Business Review, 41(3), 116-129.

Duchin, R., Ozbas, O. \& Sensoy, B. A. 2010. Costly external finance, corporate investment, and the subprime mortgage credit crisis. Journal of Financial Economics, 97(3), pp 418-435.

Dunakhir, S. 2016. Factors associated with audit quality: Evidence from an emerging market. Asia Pacific Journal of Advanced Business and Social Studies, 2(2), pp 523-533.

Dye, R. A. 1993. Auditing Standards, Legal Liability, and Auditor Wealth. Journal of Political Economy, 101(5), pp 887-914.

Eshleman, J. D. \& Guo, P. 2014. Do Big 4 Auditors Provide Higher Audit Quality after Controlling for the Endogenous Choice of Auditor? Auditing-a Journal of Practice \& Theory, 33(4), pp 197-219.

Fama, E. F. \& French, K. R. 2002. The equity premium. Journal of Finance, 57(2), pp 637-659. 
Fan, J. P. H., Wei, K. C. J. \& Xu, X. Z. 2011. Corporate finance and governance in emerging markets: A selective review and an agenda for future research. Journal of Corporate Finance, 17(2), pp 207-214.

Fan, J. P. H. \& Wong, T. J. 2002. Corporate ownership structure and the informativeness of accounting earnings in East Asia. Journal of Accounting \& Economics, 33(3), pp 401-425.

Fan, J. P. H. \& Wong, T. J. 2005. Do external auditors perform a corporate governance role in emerging markets? Evidence from East Asia. Journal of Accounting Research, 43(1), pp 3572.

Fang, L. \& Peress, J., 2009, Media coverage and the cross-section of stock returns, Journal of Finance, 64(5), pp. 2023-2052

Fischer, E. O., Heinkel, R. \& Zechner, J. 1989. Dynamic Capital Structure Choice - Theory and Tests. Journal of Finance, 44(1), pp 19-40.

Francis, J. R., Maydew, E. L. \& Sparks, H. C. 1999. The role of Big 6 auditors in the credible reporting of accruals. Auditing-a Journal of Practice \& Theory, 18(2), pp 17-34.

Francis, J. R., Michas, P. N. \& Seavey, S. E. 2013. Does Audit Market Concentration Harm the Quality of Audited Earnings? Evidence from Audit Markets in 42 Countries. Contemporary Accounting Research, 30(1), pp 325-355.

Frank, M. Z. \& Goyal, V. K. 2009. Capital Structure Decisions: Which Factors Are Reliably Important? Financial Management, 38(1), pp 1-37.

Gao, W., \& Zhu, F. (2015). Information asymmetry and capital structure around the world. PacificBasin Finance Journal, 32, 131-159.

Grossman, S. J. \& Hart, O. D. 1982. Corporate financial structure and managerial incentives. In: McCall, J. J. (ed.) The economics of information and uncertainty. Chicago: University of Chicago Press.

Guedhami, O. \& Pittman, J. A. 2011. The choice between private and public capital markets: The importance of disclosure standards and auditor discipline to countries divesting state-owned enterprises. Journal of Accounting and Public Policy, 30(5), pp 395-430.

Guedhami, O., Pittman, J. A. \& Saffar, W. 2014. Auditor Choice in Politically Connected Firms. Journal of Accounting Research, 52(1), pp 107-162.

He, X. J., Rui, O., Zheng, L. \& Zhu, H. J. 2014. Foreign ownership and auditor choice. Journal of Accounting and Public Policy, 33(4), pp 401-418.

Higgins, R. C. (1977). How much growth can a firm afford?. Financial management, 6(3), pp. 7-16.

Hogan, C.E. \& Martin, R.D. 2009, Risk shifts in the markets for audits: An examination of changes in risk for "second-tier" audit firms. Auditing: A Journal of Practice \& Theory, 28(2), pp. 93118

Houque, M. N., K. Ahmed and T. van Zijl (2017). Audit Quality, Earnings Management, and Cost of Equity Capital: Evidence from India, International Journal of Auditing, 21(2): 177-189 
Hovakimian, A., Opler, T. \& Titman, S. 2001. The debt-equity choice. Journal of Financial and Quantitative Analysis, 36(1), pp 1-24.

IDX \& IBPA 2014. Indonesian Bond Market Directory 2013 - 2014: Indonesian Stock Exchange Indonesia Bond Pricing Agency.

IFAC. 2016. IFAC [Online]. Available: https://www.ifac.org/aboutifac/membership/country/indonesia [Accessed June, 8 2017].

Indonesia Stock Exchange. 2016. Fact Book [Document file].

Jensen, M. C. \& Meckling, W. H. 1976. Theory of Firm - Managerial Behavior, Agency Costs and Ownership Structure. Journal of Financial Economics, 3(4), pp 305-360.

Johnstone, K. M. 2000. Client-acceptance decisions: Simultaneous effects of client business risk, audit risk, auditor business risk, and risk adaptation. Auditing-a Journal of Practice \& Theory, 19(1), pp 1-25.

Johnstone, K. M. \& Bedard, J. C. 2004. Audit firm portfolio management decisions. Journal of Accounting Research, 42(4), pp 659-690.

Kartikahadi, H. 2010. Pelangi di Cakrawala Profesi Akuntan (Rainbow over Accounting Profession Horizon), Indonesia: Buana Ilmu Populer Gramedia Group.

Lawrence, A., Minutti-Meza, M., \& Zhang, P. (2011). Can Big 4 versus non-Big 4 differences in audit-quality proxies be attributed to client characteristics?. The Accounting Review, 86(1), 259-286.

Leuz, C., Nanda, D. \& Wysocki, P. D. 2003. Earnings management and investor protection: an international comparison. Journal of Financial Economics, 69(3), pp 505-527.

Myers, S. C. \& Majluf, N. S. 1984. Corporate Financing and Investment Decisions When Firms Have Information That Investors Do Not Have. Journal of Financial Economics, 13(2), pp 187221.

Okere, W., U.L. Ogundipe, L. Q. Oyedeji, D. F.Eluyela, and O. K. Elizah (2018). Auditors' Choice and Financing Decision of Selected Quoted Firms in Nigeria. International Journal of Management, Accounting and Economics, 5(2): 66-77.

Oliver Wyman \& Mandiri Institute. 2015. Financial Deepening in Indonesia. Available: http://www.oliverwyman.com/content/dam/oliverwyman/global/en/2015/sep/Financial_Deepening_In_Indonesia.pdf.

Petacchi, R. 2015. Information asymmetry and capital structure: Evidence from regulation FD. Journal of Accounting \& Economics, 59(2-3), pp 143-162.

Piot, C. 2001. Agency costs and audit quality: evidence from France. European Accounting Review, 10(3), pp 461-499.

Prabowo, M. \& Simpson, J. 2011. Independent directors and firm performance in family controlled firms: evidence from Indonesia. Asian-Pacific Economic Literature, 25(1), pp 121-132.

Rajan, R. G. \& Zingales, L. 1995. What Do We Know About Capital Structure - Some Evidence from International Data. Journal of Finance, 50(5), pp 1421-1460. 
Shipman, J. E., Swanquist, Q. T., \& Whited, R. L. (2016). Propensity score matching in accounting research. The Accounting Review, 92(1), 213-244.

Simunic, D. A. \& Stein, M. T. 1996. The impact of litigation risk on audit pricing: A review of the economics and the evidence. Auditing-a Journal of Practice \& Theory, 15(119-134.

Suryanto, T., Thalassinos, J.E., Thalassinos, E.I., 2017, Board characteristics, audit committee and audit quality: The case of Indonesia, International Journal of Economics and Business Adinistration, V(3), pp. 44-57

Tabalujan, B. S. 2002. Family capitalism and corporate governance of family-controlled listed companies in Indonesia. University of New South Wales Law Journal, 25(2), pp 486-514.

Watts, R. L. \& Zimmerman, J. L. 1983. Agency Problems, Auditing, and the Theory of the Firm Some Evidence. Journal of Law \& Economics, 26(3), pp 613-633.

Wilde, J. H. (2017). The deterrent effect of employee whistleblowing on firms' financial misreporting and tax aggressiveness. The Accounting Review, 92(5), 247-280.

Wong, R.M.K., Firth, M.A., Lo, A.W.Y, 2018, The impact of litigation risk on the association between audit quality and auditor size: Evidence from China, Journal of International Financial Management and Accounting, 29, pp. 280-311.

The World Bank. 2010a. Report on the observance of standards and codes (ROSC): Accounting \& Auditing [Doc file],

The World Bank. 2010b. Report on the observance of standards and codes (ROSC): Corporate Governance [Doc File],

The World Bank. 2016. Market capitalization of listed domestic companies (\% of GDP) [Data file].

The World Bank, 2019, Available: https://www.worldbank.org/en/country indonesia/overview.

Accessed on November 28, 2019 
TABLES

Table 1: Variable definitions

\begin{tabular}{|c|c|c|}
\hline Variable & & Definition \\
\hline LTDMEQ & : & Debt ratio: long term debt /(market value of equity + book value of long term debt $)$ \\
\hline LTDEQ & : & Debt ratio: (long term debt)/(book value of equity + book value of long term debt) \\
\hline TDMEQ & : & Debt ratio: total debt/(market value of equity + book value of total debt) \\
\hline TDEQ & : & Debt ratio: total debt/(book value of equity + book value of total debt) \\
\hline BIG4 & : & $\begin{array}{l}\text { Dummy variable taking the value of } 1 \text { if the company was audited by a local audit firm } \\
\text { affiliated with a Big } 4 \text { audit firm and } 0 \text { otherwise }\end{array}$ \\
\hline SIZE & & The natural log of total assets \\
\hline ROA & & Return on assets: net income before extra items scaled by total assets. \\
\hline INDLTDMEQ & & $\begin{array}{l}\text { Industry median leverage: industry median ((long term debt }+ \text { current portion of long } \\
\text { term debt)/market value of equity) }\end{array}$ \\
\hline INDLTDEQ & : & $\begin{array}{l}\text { Industry median leverage: industry median ((long term debt }+ \text { current portion of long } \\
\text { term debt)/book value of equity) }\end{array}$ \\
\hline INDTDMEQ & $:$ & Industry median leverage: industry median (total debt/market value of equity) \\
\hline INDTDEQ & : & Industry median leverage: industry median (total debt/book value of equity) \\
\hline MTB & $:$ & $\begin{array}{l}\text { Growth and investment opportunities: market to book value of assets (total assets - } \\
\text { book value of equity }+ \text { market value of equity)/ total assets }\end{array}$ \\
\hline RET & : & $\begin{array}{l}\text { Holding period stock return over the fiscal year: (ending year stock price - beginning } \\
\text { year stock price)/beginning year stock price }\end{array}$ \\
\hline PPE & : & Tangible assets: Property, plant and equipment/total assets \\
\hline DEBTAX & : & Tax advantage debt: Current income tax/pre-tax income \\
\hline NDEBTAX & : & Non-debt tax shield: depreciation/total assets \\
\hline SDROA & : & Standard deviation of return on assets from the previous three years \\
\hline FOREIGN & : & $\begin{array}{l}\text { Dummy variable taking the value of } 1 \text { if the largest shareholder is from a foreign } \\
\text { country and } 0 \text { otherwise }\end{array}$ \\
\hline OWN & : & Percentage of closely held shares \\
\hline CROSS & : & Dummy variable taking the value of 1 if the company is cross-listed, and 0 otherwise \\
\hline STATE & : & Dummy variable taking the value of 1 if a company is state-owned and 0 otherwise \\
\hline ATURN & : & Asset turnover/ total sales/total assets \\
\hline CURR & : & Current assets/total assets \\
\hline LEV & : & Leverage: long term debt/total assets \\
\hline LOSS & $:$ & $\begin{array}{l}\text { Dummy variable taking the value of } 1 \text { if the company experienced negative net income } \\
\text { before extraordinary items in the prior year, and } 0 \text { otherwise }\end{array}$ \\
\hline
\end{tabular}


Table 2 : Sample selection method

\begin{tabular}{lcc}
\hline & drop & $\begin{array}{c}\text { firm- } \\
\text { years }\end{array}$ \\
\hline Initial sample* & & 2,573 \\
Companies that had total assets growth $>100 \%$ & $(64)$ & \\
Subsidiary companies & $(138)$ & \\
Companies with missing values variables & $(394)$ & \\
\hline Final sample & & 1,977 \\
\hline
\end{tabular}

Table 3: Sample breakdown by year and industry

\begin{tabular}{cccccc}
\hline & \multicolumn{2}{c}{ Sample } & \multicolumn{2}{c}{ initial sample* } & \multirow{2}{*}{$\begin{array}{c}\text { \% Final sample to initial } \\
\text { sample }\end{array}$} \\
\cline { 2 - 5 } Panel A: by year & $\#$ & $\%$ & \# & $\%$ & 69.71 \\
2008 & 191 & 9.66 & 274 & 10.65 & 72.86 \\
2009 & 204 & 10.32 & 280 & 10.88 & 68.69 \\
2010 & 204 & 10.32 & 297 & 11.54 & 78.91 \\
2011 & 247 & 12.49 & 313 & 12.16 & 76.29 \\
2012 & 251 & 12.70 & 329 & 12.79 & 78.51 \\
2013 & 274 & 13.86 & 349 & 13.56 & 82.27 \\
2014 & 297 & 15.02 & 361 & 14.03 & 83.51 \\
2015 & 309 & 15.63 & 370 & 14.38 & \\
\hline Total & 1,977 & 100 & 2,573 & 100 & \\
\hline
\end{tabular}

\begin{tabular}{lccccc}
\hline \multirow{2}{*}{ Panel B: by industry } & Sample & \multicolumn{3}{c}{ Initial sample* } & \multirow{2}{*}{$\begin{array}{c}\text { Final sample to initial } \\
\text { sample }\end{array}$} \\
\cline { 2 - 5 } & $\#$ & $\%$ & $\#$ & $\%$ & 80.07 \\
\hline Basic materials & 450 & 22.76 & 562 & 21.84 & 80.06 \\
Consumer goods & 546 & 27.62 & 682 & 26.51 & 68.29 \\
Consumer services & 308 & 15.58 & 451 & 17.53 & 82.61 \\
Health care & 76 & 3.84 & 92 & 3.58 & 77.51 \\
Industrials & 424 & 21.45 & 547 & 21.26 & 75.86 \\
Oil \& gas & 44 & 2.23 & 58 & 2.25 & 61.47 \\
Technology & 67 & 3.39 & 109 & 4.24 & 85.96 \\
Telecommunication & 49 & 2.48 & 57 & 2.22 & 86.67 \\
Utilities & 13 & 0.66 & 15 & 0.58 & \\
\hline Total & 1,977 & 100 & 2,573 & 100 & \\
\hline
\end{tabular}

* Initial sample of all Indonesian listed non-financial companies over the 2008-2015 period

Industry groups are based on the Industry Classification Benchmark (ICB) universe retrieved from Worldscope/Datastream. 
Table 4: Descriptive statistics

\begin{tabular}{|c|c|c|c|c|c|c|c|}
\hline & Mean & SD & p10 & Median & p90 & Min & Max \\
\hline LTDMEQ & 0.2331 & 0.2625 & 0 & 0.1291 & 0.6735 & 0 & 0.8802 \\
\hline LTDEQ & 0.2553 & 0.2773 & 0 & 0.1735 & 0.6266 & -0.0285 & 1.1348 \\
\hline TDMEQ & 0.3208 & 0.2791 & 0.0002 & 0.2644 & 0.7583 & 0 & 0.9054 \\
\hline TDEQ & 0.3694 & 0.3194 & 0.0000 & 0.3431 & 0.7262 & 0 & 1.5628 \\
\hline BIG4 & 0.3859 & 0.4869 & 0 & 0 & 1 & 0 & 1 \\
\hline SIZE & 21.2130 & 1.7439 & 18.9436 & 21.2045 & 23.5690 & 17.2326 & 24.7982 \\
\hline ROA & 0.0365 & 0.1030 & -0.0661 & 0.0319 & 0.1448 & -0.2765 & 0.3428 \\
\hline INDLTDMEQ & 0.1398 & 0.0835 & 0.0652 & 0.1298 & 0.2553 & 0.0009 & 0.4330 \\
\hline INDLTDEQ & 0.1831 & 0.0936 & 0.1029 & 0.1671 & 0.2571 & 0.0034 & 0.5632 \\
\hline INDTDMEQ & 0.2620 & 0.0967 & 0.1838 & 0.2531 & 0.3719 & 0.0148 & 0.4732 \\
\hline INDTDEQ & 0.3433 & 0.0887 & 0.2719 & 0.3586 & 0.4268 & 0.0488 & 0.5640 \\
\hline МТВ & 1.7065 & 1.5634 & 0.7087 & 1.1468 & 3.2376 & 0.4722 & 9.1356 \\
\hline RET & 0.1494 & 0.6589 & -0.4772 & 0 & 0.9774 & -0.7658 & 2.6297 \\
\hline PPE & 0.3912 & 0.2398 & 0.0762 & 0.3675 & 0.7440 & 0.0139 & 0.9020 \\
\hline DEBTTAX & 0.1787 & 0.2122 & 0 & 0.2100 & 0.4010 & -0.3265 & 0.8772 \\
\hline NDEBTTAX & 0.0392 & 0.0310 & 0.0082 & 0.0323 & 0.0810 & 0.0011 & 0.1478 \\
\hline SDROA & 0.0486 & 0.0714 & 0.0053 & 0.0245 & 0.1119 & 0.0014 & 0.3774 \\
\hline FOREIGN & 0.2969 & 0.4570 & 0 & 0 & 1 & 0 & 1 \\
\hline OWN & 0.6866 & 0.1957 & 0.4320 & 0.7126 & 0.9217 & 0.1428 & 0.9800 \\
\hline CROSS & 0.4107 & 0.4921 & 0 & 0 & 1 & 0 & 1 \\
\hline STATE & 0.0607 & 0.2388 & 0 & 0 & 0 & 0 & 1 \\
\hline ATURN & 1.0329 & 0.7568 & 0.2047 & 0.8967 & 2.0214 & 0.0404 & 3.4305 \\
\hline CURR & 0.4937 & 0.2396 & 0.1572 & 0.4920 & 0.8206 & 0.0625 & 0.9366 \\
\hline LEV & 0.1343 & 0.1674 & 0 & 0.0674 & 0.3752 & 0.0000 & 0.7048 \\
\hline LOSS & 0.1887 & 0.3913 & 0 & 0 & 1 & 0 & 1 \\
\hline $\mathbf{N}$ & 1,977 & & & & & & \\
\hline
\end{tabular}

For variable definitions: see Table 1. 
Panel B: By audit firm type

\begin{tabular}{|c|c|c|c|c|c|c|c|c|c|c|}
\hline \multirow[b]{3}{*}{ LTDMEQ } & \multicolumn{3}{|c|}{ BIG4 } & \multicolumn{3}{|c|}{ NON-BIG4 } & \multirow{2}{*}{\multicolumn{2}{|c|}{ t-test }} & \multirow{2}{*}{\multicolumn{2}{|c|}{ z-test }} \\
\hline & \multirow{2}{*}{$\begin{array}{l}\text { Mean } \\
0.2065\end{array}$} & \multirow{2}{*}{$\frac{\text { SD }}{0.2496}$} & \multirow{2}{*}{$\begin{array}{r}\text { Median } \\
0.1068\end{array}$} & \multirow{2}{*}{$\begin{array}{l}\text { Mean } \\
0.2499\end{array}$} & \multirow{2}{*}{$\begin{array}{l}\text { SD } \\
0.2690\end{array}$} & \multirow{2}{*}{$\begin{array}{r}\text { Median } \\
0.1460\end{array}$} & & & & \\
\hline & & & & & & & -3.66 & $* * *$ & -3.97 & $* * *$ \\
\hline LTDEQ & 0.2584 & 0.2728 & 0.1904 & 0.2533 & 0.2802 & 0.1672 & 0.41 & & 0.154 & \\
\hline TDMEQ & 0.2837 & 0.2711 & 0.2088 & 0.3441 & 0.2816 & 0.2905 & -4.75 & $* * *$ & -4.73 & $* * *$ \\
\hline TDEQ & 0.3530 & 0.2911 & 0.3314 & 0.3797 & 0.3357 & 0.3505 & -1.87 & & 1.01 & \\
\hline SIZE & 22.1474 & 1.4480 & 22.1378 & 20.6257 & 1.6562 & 20.6178 & 21.5 & $* * *$ & 19.2 & $* * *$ \\
\hline ROA & 0.0689 & 0.1048 & 0.0530 & 0.0161 & 0.0965 & 0.0238 & 11.25 & $* * *$ & 10.17 & $* * *$ \\
\hline INDLTDMEQ & 0.1432 & 0.0887 & 0.1298 & 0.1376 & 0.0800 & 0.1298 & 1.41 & & 0.69 & \\
\hline INDLTDEQ & 0.1851 & 0.1032 & 0.1647 & 0.1818 & 0.0871 & 0.1671 & -0.75 & & -1.21 & \\
\hline INDTDMEQ & 0.2630 & 0.0980 & 0.2531 & 0.2614 & 0.0959 & 0.2531 & 0.37 & & 0.33 & \\
\hline INDTDEQ & 0.3431 & 0.0938 & 0.3522 & 0.3435 & 0.0854 & 0.3586 & -0.08 & & -0.54 & \\
\hline МТВ & 1.9929 & 1.7466 & 1.3657 & 1.5265 & 1.4075 & 1.0734 & 6.21 & $* * *$ & 8.56 & $* * *$ \\
\hline RET & 0.1704 & 0.6834 & 0 & 0.1361 & 0.6429 & 0 & 1.11 & & 0.79 & \\
\hline PPE & 0.4043 & 0.2129 & 0.3773 & 0.3829 & 0.2551 & 0.3547 & 2.01 & $* *$ & 2.64 & $* * *$ \\
\hline DEBTTAX & 0.2203 & 0.2089 & 0.2499 & 0.1526 & 0.2101 & 0.1111 & 6.99 & $* *$ & 8.65 & $* * *$ \\
\hline NDEBTTAX & 0.0428 & 0.0283 & 0.0374 & 0.0369 & 0.0324 & 0.0285 & 4.27 & $* * *$ & 7.45 & $* * *$ \\
\hline SDROA & 0.0426 & 0.0542 & 0.0259 & 0.0524 & 0.0802 & 0.0232 & -3.24 & $* * *$ & 1.71 & $*$ \\
\hline FOREIGN & 0.4168 & 0.4933 & 0 & 0.2216 & 0.4155 & 0 & 9.09 & $* * *$ & 9.24 & $* * *$ \\
\hline OWN & 0.7139 & 0.1726 & 0.7278 & 0.6695 & 0.2071 & 0.7070 & 5.15 & $* * *$ & 3.94 & $* * *$ \\
\hline CROSS & 0.5544 & 0.4974 & 1 & 0.3204 & 0.4668 & 0 & 10.42 & $* * *$ & 10.29 & $* * *$ \\
\hline STATE & 0.0865 & 0.2813 & 0 & 0.0445 & 0.2062 & 0 & 3.56 & $* * *$ & 3.81 & $* * *$ \\
\hline ATURN & 1.1403 & 0.7468 & 0.9596 & 0.9654 & 0.7555 & 0.8309 & 5.05 & $* * *$ & 5.92 & $* * *$ \\
\hline CURR & 0.4886 & 0.2142 & 0.4821 & 0.4969 & 0.2543 & 0.5021 & -0.78 & & -0.86 & \\
\hline LEV & 0.1346 & 0.1577 & 0.0795 & 0.1341 & 0.1733 & 0.0567 & 0.06 & & -0.07 & \\
\hline LOSS & 0.1350 & 0.3419 & 0 & 0.2224 & 0.4160 & 0 & -5.08 & $* * *$ & -4.84 & $* * *$ \\
\hline $\mathbf{N}$ & 763 & & & 1214 & & & & & & \\
\hline
\end{tabular}


Table 5: Pearson \& Spearman correlation

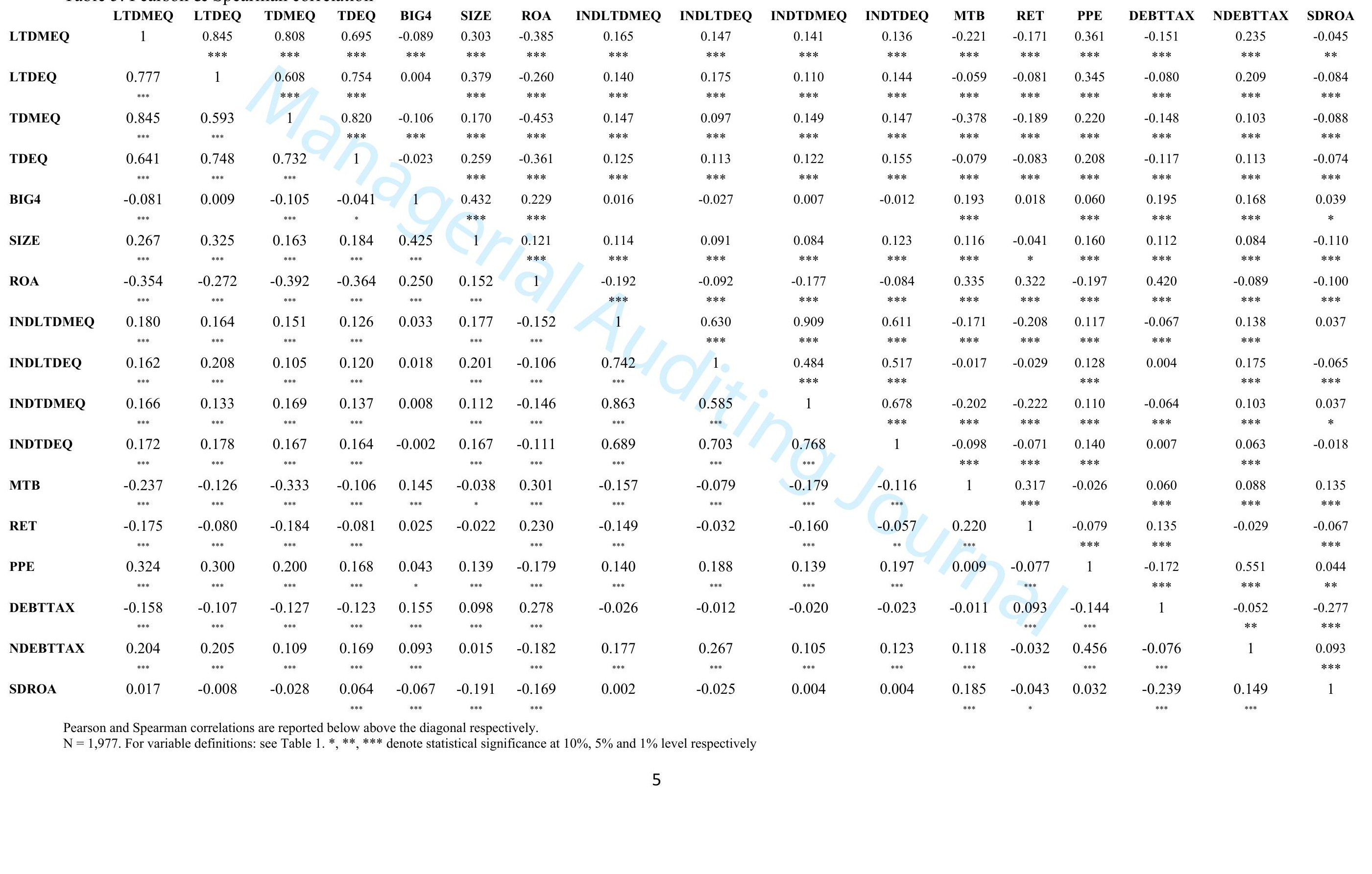


Table 6A: Two-way clustered SE OLS estimation on Big4

\begin{tabular}{|c|c|c|c|c|c|}
\hline & & LTDMEQ & LTDEQ & TDMEQ & TDEQ \\
\hline CONSTANT & & $\begin{array}{l}-0.870 \\
(5.83)^{* * *}\end{array}$ & $\begin{array}{l}-1.060 \\
(6.61)^{* * *}\end{array}$ & $\begin{array}{l}-0.422 \\
(2.53)^{* *}\end{array}$ & $\begin{array}{l}-0.740 \\
(4.00)^{* * *}\end{array}$ \\
\hline BIG4 & $(-)$ & $\begin{array}{l}-0.081 \\
(3.71)^{* * * *}\end{array}$ & $\begin{array}{l}-0.054 \\
(2.13)^{* * *}\end{array}$ & $\begin{array}{l}-0.056 \\
(2.04)^{* *}\end{array}$ & $\begin{array}{l}-0.046 \\
(1.51)\end{array}$ \\
\hline SIZE & $(+)$ & $\begin{array}{l}0.052 \\
(6.96)^{* * *}\end{array}$ & $\begin{array}{l}0.060 \\
(7.23)^{* * *}\end{array}$ & $\begin{array}{l}0.036 \\
(4.48)^{* * *}\end{array}$ & $\begin{array}{l}0.050 \\
(5.30)^{* * *}\end{array}$ \\
\hline ROA & $(-)$ & $\begin{array}{l}-0.633 \\
(6.48)^{* * *}\end{array}$ & $\begin{array}{l}-0.655 \\
(5.34)^{* * *}\end{array}$ & $\begin{array}{l}-0.794 \\
(6.52)^{* * *}\end{array}$ & $\begin{array}{l}-1.129 \\
(6.34)^{* * *}\end{array}$ \\
\hline INDLTMDEQ & $(+)$ & $\begin{array}{r}0.075 \\
(0.64)\end{array}$ & & & \\
\hline INDLTDEQ & $(+)$ & & $\begin{array}{c}0.168 \\
(1.41)\end{array}$ & & \\
\hline INDTDMEQ & $(+)$ & & & $\begin{array}{c}0.244 \\
(1.77)^{*}\end{array}$ & \\
\hline INDTDEQ & $(+)$ & & & & $\begin{array}{c}0.241 \\
(1.91)^{*}\end{array}$ \\
\hline MTB & $( \pm)$ & $\begin{array}{l}-0.022 \\
(3.70)^{* * *}\end{array}$ & $\begin{array}{l}-0.006 \\
(0.91)\end{array}$ & $\begin{array}{l}-0.036 \\
(5.33)^{* * *}\end{array}$ & $\begin{array}{c}0.004 \\
(0.35)\end{array}$ \\
\hline RET & $(-)$ & $\begin{array}{l}-0.026 \\
(3.03)^{* * *}\end{array}$ & $\begin{array}{c}0.004 \\
(0.62)\end{array}$ & $\begin{array}{l}-0.030 \\
(3.92)^{* * *}\end{array}$ & $\begin{array}{l}-0.001 \\
(0.13)\end{array}$ \\
\hline PPE & $(+)$ & $\begin{array}{l}0.202 \\
(4.57)^{* * *}\end{array}$ & $\begin{array}{l}0.185 \\
(4.08)^{* * *}\end{array}$ & $\begin{array}{l}0.101 \\
(1.99)^{* *}\end{array}$ & $\begin{array}{c}0.020 \\
(0.34)\end{array}$ \\
\hline DEBTAX & $(+)$ & $\begin{array}{l}-0.086 \\
(2.93)^{* * *}\end{array}$ & $\begin{array}{l}-0.063 \\
(1.88)^{*}\end{array}$ & $\begin{array}{l}-0.067 \\
(1.50)\end{array}$ & $\begin{array}{l}-0.065 \\
(1.49)\end{array}$ \\
\hline NDEBTAX & $( \pm)$ & $\begin{array}{c}0.718 \\
(1.46)\end{array}$ & $\begin{array}{r}0.679 \\
(1.35)\end{array}$ & $\begin{array}{r}0.337 \\
(0.67)\end{array}$ & $\begin{array}{c}0.807 \\
(1.36)\end{array}$ \\
\hline SDROA & $(-)$ & $\begin{array}{c}0.071 \\
(0.56)\end{array}$ & $\begin{array}{l}-0.015 \\
(0.11)\end{array}$ & $\begin{array}{l}-0.097 \\
(0.63)\end{array}$ & $\begin{array}{c}0.092 \\
(0.36)\end{array}$ \\
\hline Time dummies & & Yes & Yes & Yes & Yes \\
\hline $\mathrm{R} 2$ & & 0.33 & 0.27 & 0.29 & 0.22 \\
\hline $\mathrm{N}$ & & 1,977 & 1,977 & 1,977 & 1,977 \\
\hline
\end{tabular}

For variable definitions: see Table 1 .

$*, * *, * * *$ denote statistical significance at $10 \%, 5 \%$ and $1 \%$ level respectively 
Table 6B: Propensity Score Matching on Big4

\begin{tabular}{|c|c|c|c|c|c|}
\hline & & LTDMEQ & LTDEQ & TDMEQ & TDEQ \\
\hline CONSTANT & & $\begin{array}{r}-1.013 \\
(11.26)^{* * *}\end{array}$ & $\begin{array}{r}-1.169 \\
(11.24)^{* * *}\end{array}$ & $\begin{array}{r}-0.113 \\
(1.02)\end{array}$ & $\begin{array}{r}-0.516 \\
(3.96) * * *\end{array}$ \\
\hline BIG4 & $(-)$ & $\begin{array}{r}-0.048 \\
(3.42)^{* * * *}\end{array}$ & $\begin{array}{r}-0.031 \\
(1.93)^{*}\end{array}$ & $\begin{array}{r}-0.054 \\
(3.46)^{* * * *}\end{array}$ & $\begin{array}{c}-0.038 \\
(2.00)^{* * *}\end{array}$ \\
\hline SIZE & $(+)$ & $\begin{array}{r}0.059 \\
(13.76)^{* * *}\end{array}$ & $\begin{array}{r}0.064 \\
(12.87)^{* * *}\end{array}$ & $\begin{array}{r}0.027 \\
(5.47)^{* * *}\end{array}$ & $\begin{array}{c}0.041 \\
(6.56)^{* * *}\end{array}$ \\
\hline $\mathrm{ROA}$ & $(-)$ & $\begin{array}{c}-0.845 \\
(9.62)^{* * *}\end{array}$ & $\begin{array}{r}-0.888 \\
(7.13)^{* * *}\end{array}$ & $\begin{array}{r}-1.074 \\
(10.64)^{* * *}\end{array}$ & $\begin{array}{c}-1.419 \\
(9.23)^{* * *}\end{array}$ \\
\hline INDLTMDEQ & $(+)$ & $\begin{array}{r}0.017 \\
(0.19)\end{array}$ & & & \\
\hline INDLTDEQ & $(+)$ & & $\begin{array}{r}0.187 \\
(2.42)^{* *}\end{array}$ & & \\
\hline INDTDMEQ & $(+)$ & & & $\begin{array}{r}0.045 \\
(0.52)\end{array}$ & \\
\hline INDTDEQ & & & & & $\begin{array}{r}0.302 \\
(3.23)^{* * *}\end{array}$ \\
\hline MTB & $( \pm)$ & $\begin{array}{c}-0.023 \\
(4.28)^{* * *}\end{array}$ & $\begin{array}{r}0.006 \\
(0.81)\end{array}$ & $\begin{array}{r}-0.048 \\
(8.09)^{* * *}\end{array}$ & $\begin{array}{c}0.011 \\
(1.08)\end{array}$ \\
\hline RET & $(-)$ & $\begin{array}{l}-0.019 \\
(1.90)^{*}\end{array}$ & $\begin{array}{r}-0.001 \\
(0.13)\end{array}$ & $\begin{array}{r}-0.011 \\
(0.90)\end{array}$ & $\begin{array}{c}0.004 \\
(0.25)\end{array}$ \\
\hline PPE & $(+)$ & $\begin{array}{c}0.236 \\
(6.53)^{* * *}\end{array}$ & $\begin{array}{r}0.183 \\
(4.70)^{* * *}\end{array}$ & $\begin{array}{r}0.076 \\
(2.01)^{* *}\end{array}$ & $\begin{array}{r}-0.090 \\
(1.98)^{* *}\end{array}$ \\
\hline DEBTAX & $(+)$ & $\begin{array}{c}-0.085 \\
(2.33)^{* *}\end{array}$ & $\begin{array}{r}-0.096 \\
(2.58)^{* *}\end{array}$ & $\begin{array}{r}-0.085 \\
(2.33)^{* *}\end{array}$ & $\begin{array}{r}-0.090 \\
(2.43)^{* *}\end{array}$ \\
\hline NDEBTAX & $( \pm)$ & $\begin{array}{r}0.034 \\
(0.13)\end{array}$ & $\begin{array}{r}0.297 \\
(0.82)\end{array}$ & $\begin{array}{r}-0.074 \\
(0.26)\end{array}$ & $\begin{array}{c}0.720 \\
(1.90)^{*}\end{array}$ \\
\hline SDROA & $(-)$ & $\begin{array}{c}0.399 \\
(2.81)^{* * *}\end{array}$ & $\begin{array}{r}0.313 \\
(1.57)\end{array}$ & $\begin{array}{l}0.199 \\
(1.02)\end{array}$ & $\begin{array}{c}0.647 \\
(2.36)^{* *}\end{array}$ \\
\hline Time dummies & & Yes & Yes & Yes & Yes \\
\hline $\mathrm{R} 2$ & & 0.40 & 0.32 & 0.37 & 0.28 \\
\hline $\mathrm{N}$ & & 1,072 & 1,071 & 1,079 & 1,053 \\
\hline
\end{tabular}


Table 6C: Entropy Balance on Big4

\begin{tabular}{|c|c|c|c|c|c|}
\hline & & LTDMEQ & LTDEQ & TDMEQ & TDEQ \\
\hline CONSTANT & & $\begin{array}{l}-1.037 \\
(6.58)^{* * *}\end{array}$ & $\begin{array}{l}-1.434 \\
(6.64)^{* * *}\end{array}$ & $\begin{array}{l}-0.410 \\
(2.51)^{* *}\end{array}$ & $\begin{array}{l}-0.906 \\
(4.38)^{* * *}\end{array}$ \\
\hline BIG4 & $(-)$ & $\begin{array}{l}-0.065 \\
(3.06)^{* * * *}\end{array}$ & $\begin{array}{l}-0.051 \\
(1.96)^{* * *}\end{array}$ & $\begin{array}{l}-0.049 \\
(2.34)^{* * *}\end{array}$ & $\begin{array}{l}-0.063 \\
(2.51)^{* *}\end{array}$ \\
\hline SIZE & $(+)$ & $\begin{array}{l}0.060 \\
(7.45)^{* * *}\end{array}$ & $\begin{array}{l}0.080 \\
(7.13)^{* * *}\end{array}$ & $\begin{array}{l}0.033 \\
(4.14)^{* * *}\end{array}$ & $\begin{array}{l}0.059 \\
(5.50)^{* * *}\end{array}$ \\
\hline $\mathrm{ROA}$ & $(-)$ & $\begin{array}{l}-0.910 \\
(7.19)^{* * *}\end{array}$ & $\begin{array}{l}-1.177 \\
(6.60)^{* * *}\end{array}$ & $\begin{array}{l}-1.135 \\
(8.07)^{* * *}\end{array}$ & $\begin{array}{l}-1.642 \\
(8.39)^{* * * *}\end{array}$ \\
\hline INDLTMDEQ & $(+)$ & $\begin{array}{l}0.220 \\
(1.97)^{* *}\end{array}$ & & & \\
\hline INDLTDEQ & $(+)$ & & $\begin{array}{l}0.112 \\
(1.01)\end{array}$ & & \\
\hline INDTDMEQ & $(+)$ & & & $\begin{array}{l}0.360 \\
(3.29)^{* * *}\end{array}$ & \\
\hline INDTDEQ & & & & & $\begin{array}{l}0.389 \\
(3.03) * * *\end{array}$ \\
\hline MTB & $( \pm)$ & $\begin{array}{l}-0.018 \\
(3.09)^{* * *}\end{array}$ & $\begin{array}{l}0.002 \\
(0.27)\end{array}$ & $\begin{array}{l}-0.033 \\
(5.21)^{* * *}\end{array}$ & $\begin{array}{l}0.003 \\
(0.29)\end{array}$ \\
\hline RET & $(-)$ & $\begin{array}{l}0.002 \\
(0.09)\end{array}$ & $\begin{array}{l}0.012 \\
(0.63)\end{array}$ & $\begin{array}{l}0.003 \\
(0.20)\end{array}$ & $\begin{array}{l}0.000 \\
(0.02)\end{array}$ \\
\hline PPE & $(+)$ & $\begin{array}{l}0.090 \\
(1.70)^{*}\end{array}$ & $\begin{array}{l}0.111 \\
(1.54)\end{array}$ & $\begin{array}{l}-0.034 \\
(0.58)\end{array}$ & $\begin{array}{l}-0.179 \\
(2.22)^{* *}\end{array}$ \\
\hline DEBTAX & $(+)$ & $\begin{array}{l}-0.105 \\
(1.73)^{*}\end{array}$ & $\begin{array}{l}-0.090 \\
(1.15)\end{array}$ & $\begin{array}{l}-0.110 \\
(1.99)^{* *}\end{array}$ & $\begin{array}{l}-0.175 \\
(2.32)^{* *}\end{array}$ \\
\hline NDEBTAX & $( \pm)$ & $\begin{array}{l}0.967 \\
(2.19)^{* *}\end{array}$ & $\begin{array}{l}0.476 \\
(0.71)\end{array}$ & $\begin{array}{l}0.617 \\
(1.36)\end{array}$ & $\begin{array}{l}1.479 \\
(2.35)^{* *}\end{array}$ \\
\hline SDROA & $(-)$ & $\begin{array}{l}0.365 \\
(1.73)^{*}\end{array}$ & $\begin{array}{l}0.653 \\
(2.69)^{* * *}\end{array}$ & $\begin{array}{l}0.303 \\
(1.29)\end{array}$ & $\begin{array}{l}0.710 \\
(2.40)^{* *}\end{array}$ \\
\hline $\begin{array}{l}\text { Time dummies } \\
\text { R2 }\end{array}$ & & $\begin{array}{l}\text { Yes } \\
0.44\end{array}$ & $\begin{array}{r}\text { Yes } \\
0.43\end{array}$ & $\begin{array}{l}\text { Yes } \\
0.43\end{array}$ & $\begin{array}{l}\text { Yes } \\
0.43\end{array}$ \\
\hline $\mathrm{N}$ & & 1,977 & 1,977 & 1,977 & 1,977 \\
\hline
\end{tabular}

For variable definitions: see Table 1 .

$*, * *, * *$ denote statistical significance at $10 \%, 5 \%$ and $1 \%$ level respectively 
Table 7A: Two-way clustered OLS on Big4 and second-tier as one category

\begin{tabular}{|c|c|c|c|c|c|c|c|c|c|}
\hline & & \multicolumn{4}{|c|}{ BIG4\&2NDTIER } & \multicolumn{4}{|c|}{ 2NDTIER ONLY } \\
\hline & & LTDMEQ & LTDEQ & TDMEQ & TDEQ & LTDMEQ & LTDEQ & TDMEQ & TDEQ \\
\hline CONSTANT & & $\begin{array}{c}-0.799 \\
(5.59)^{* * *}\end{array}$ & $\begin{array}{l}-1.008 \\
(6.78)^{* * *}\end{array}$ & $\begin{array}{r}-0.357 \\
(2.30)^{* *}\end{array}$ & $\begin{array}{l}-0.698 \\
(4.13)^{* * *}\end{array}$ & $\begin{array}{r}-1.040 \\
(6.10)^{* * *}\end{array}$ & $\begin{array}{r}-1.137 \\
(6.11)^{* * *}\end{array}$ & $\begin{array}{r}-0.807 \\
(4.65)^{* * *}\end{array}$ & $\begin{array}{r}-1.055 \\
(4.76)^{* * *}\end{array}$ \\
\hline BIG4\&2NDTIER & $(-)$ & $\begin{array}{r}-0.061 \\
(3.28)^{* * * *}\end{array}$ & $\begin{array}{l}-0.038 \\
(\mathbf{1 . 7 8})^{*}\end{array}$ & $\begin{array}{r}-0.034 \\
(1.49)\end{array}$ & $\begin{array}{l}-0.033 \\
(1.32)\end{array}$ & & & & \\
\hline 2NDTIER & $(-)$ & & & & & $\begin{array}{l}0.004 \\
(0.16)\end{array}$ & $\begin{array}{r}0.004 \\
(0.13)\end{array}$ & $\begin{array}{r}0.026 \\
(0.86)\end{array}$ & $\begin{array}{r}0.003 \\
(0.11)\end{array}$ \\
\hline SIZE & $(+)$ & $\begin{array}{r}0.049 \\
(6.84)^{* * *}\end{array}$ & $\begin{array}{l}0.058 \\
(7.51)^{* * *}\end{array}$ & $\begin{array}{r}0.033 \\
(4.37)^{* * *}\end{array}$ & $\begin{array}{l}0.049 \\
(5.55)^{* * *}\end{array}$ & $\begin{array}{r}0.058 \\
(6.59)^{* * *}\end{array}$ & $\begin{array}{r}0.064 \\
(6.43)^{* * *}\end{array}$ & $\begin{array}{r}0.050 \\
(6.14)^{* * *}\end{array}$ & $\begin{array}{r}0.064 \\
(5.96)^{* * *}\end{array}$ \\
\hline ROA & $(-)$ & $\begin{array}{r}-0.651 \\
(6.63)^{* * *}\end{array}$ & $\begin{array}{l}-0.668 \\
(5.36)^{* * *}\end{array}$ & $\begin{array}{r}-0.812 \\
(6.74)^{* * *}\end{array}$ & $\begin{array}{l}-1.139 \\
(6.42)^{* * *}\end{array}$ & $\begin{array}{r}-0.500 \\
(4.11)^{* * * *}\end{array}$ & $\begin{array}{r}-0.456 \\
(2.74) * * *\end{array}$ & $\begin{array}{r}-0.620 \\
(3.99)^{* * *}\end{array}$ & $\begin{array}{r}-0.937 \\
(4.58)^{* * *}\end{array}$ \\
\hline INDLTMDEQ & $(+)$ & $\begin{array}{c}0.058 \\
(0.49)\end{array}$ & & & & $\begin{array}{r}0.213 \\
(1.59)\end{array}$ & & & \\
\hline INDLTDEQ & $(+)$ & & $\begin{array}{c}0.170 \\
(1.43)\end{array}$ & & & & $\begin{array}{c}0.175 \\
(1.31)\end{array}$ & & \\
\hline INDTDMEQ & $(+)$ & & & $\begin{array}{r}0.195 \\
(1.71)^{*}\end{array}$ & & & & $\begin{array}{r}0.302 \\
(1.81)^{*}\end{array}$ & \\
\hline INDTDEQ & $(+)$ & & & & $\begin{array}{c}0.238 \\
(1.89)^{*}\end{array}$ & & & & $\begin{array}{r}0.273 \\
(1.44)\end{array}$ \\
\hline MTB & $( \pm)$ & $\begin{array}{c}-0.023 \\
(3.97)^{* * *}\end{array}$ & $\begin{array}{l}-0.007 \\
(1.08)\end{array}$ & $\begin{array}{r}-0.037 \\
(5.58)^{* * *}\end{array}$ & $\begin{array}{r}0.003 \\
(0.27)\end{array}$ & $\begin{array}{r}-0.021 \\
(2.38)^{* *}\end{array}$ & $\begin{array}{r}-0.006 \\
(0.57)\end{array}$ & $\begin{array}{r}-0.034 \\
(3.67)^{* * *}\end{array}$ & $\begin{array}{l}0.005 \\
(0.33)\end{array}$ \\
\hline RET & $(-)$ & $\begin{array}{c}-0.025 \\
(3.15)^{* * *}\end{array}$ & $\begin{array}{r}0.004 \\
(0.70)\end{array}$ & $\begin{array}{r}-0.029 \\
(4.00)^{* * *}\end{array}$ & $\begin{array}{l}-0.001 \\
(0.10)\end{array}$ & $\begin{array}{r}-0.028 \\
(2.17)^{* *}\end{array}$ & $\begin{array}{c}-0.000 \\
(0.02)\end{array}$ & $\begin{array}{r}-0.036 \\
(2.95)^{* * * *}\end{array}$ & $\begin{array}{l}-0.011 \\
(0.74)\end{array}$ \\
\hline PPE & $(+)$ & $\begin{array}{r}0.204 \\
(4.60)^{* * *}\end{array}$ & $\begin{array}{l}0.187 \\
(4.10)^{* * *}\end{array}$ & $\begin{array}{r}0.103 \\
(2.03)^{* *}\end{array}$ & $\begin{array}{c}0.021 \\
(0.36)\end{array}$ & $\begin{array}{r}0.193 \\
(3.72)^{* * *}\end{array}$ & $\begin{array}{r}0.171 \\
(3.21)^{* * * *}\end{array}$ & $\begin{array}{r}0.116 \\
(1.94)^{*}\end{array}$ & $\begin{array}{l}0.026 \\
(0.38)\end{array}$ \\
\hline DEBTAX & $(+)$ & $\begin{array}{c}-0.090 \\
(3.05)^{* * *}\end{array}$ & $\begin{array}{l}-0.066 \\
(1.95)^{*}\end{array}$ & $\begin{array}{r}-0.071 \\
(1.57)\end{array}$ & $\begin{array}{l}-0.067 \\
(1.53)\end{array}$ & $\begin{array}{r}-0.083 \\
(2.26)^{* *}\end{array}$ & $\begin{array}{r}-0.053 \\
(1.30)\end{array}$ & $\begin{array}{c}-0.020 \\
(0.36)\end{array}$ & $\begin{array}{c}-0.028 \\
(0.46)\end{array}$ \\
\hline NDEBTAX & $( \pm)$ & $\begin{array}{c}0.648 \\
(1.32)\end{array}$ & $\begin{array}{r}0.622 \\
(1.25)\end{array}$ & $\begin{array}{l}0.276 \\
(0.55)\end{array}$ & $\begin{array}{c}0.762 \\
(1.30)\end{array}$ & $\begin{array}{r}1.263 \\
(2.02)^{* *}\end{array}$ & $\begin{array}{l}0.970 \\
(1.48)\end{array}$ & $\begin{array}{r}1.191 \\
(1.80)^{*}\end{array}$ & $\begin{array}{r}1.404 \\
(1.71)^{*}\end{array}$ \\
\hline SDROA & $(-)$ & $\begin{array}{c}0.062 \\
(0.49)\end{array}$ & $\begin{array}{l}-0.021 \\
(0.15)\end{array}$ & $\begin{array}{r}-0.103 \\
(0.67)\end{array}$ & $\begin{array}{c}0.088 \\
(0.34)\end{array}$ & $\begin{array}{r}0.040 \\
(0.27)\end{array}$ & $\begin{array}{l}-0.186 \\
(1.44)\end{array}$ & $\begin{array}{r}-0.073 \\
(0.43)\end{array}$ & $\begin{array}{r}0.011 \\
(0.04)\end{array}$ \\
\hline Time dummies & & Yes & Yes & Yes & Yes & Yes & Yes & Yes & Yes \\
\hline
\end{tabular}




\begin{tabular}{lccccccccc}
$\mathrm{R} 2$ & 0.32 & 0.27 & 0.28 & 0.22 & 0.33 & 0.26 & 0.28 & 0.22 & 1,28 \\
\hline $\mathrm{N}$ & 1,977 & 1,977 & 1,977 & 1,977 & 1,214 & 1,214 & 1,214 & 1,214 \\
\hline
\end{tabular}

For variable definitions: see Table

$*, * *, * * *$ denote statistical significance at $10 \%, 5 \%$ and $1 \%$ level respectively 
Tabel 7B PSM analysis on Big4 and second-tier as one category

\begin{tabular}{|c|c|c|c|c|c|c|c|c|c|}
\hline & & \multicolumn{4}{|c|}{ BIG4\&2NDTIER } & \multicolumn{4}{|c|}{ 2NDTIER ONLY } \\
\hline & & LTDMEQ & LTDEQ & TDMEQ & TDEQ & LTDMEQ & LTDEQ & TDMEQ & TDEQ \\
\hline & & $x^{2}=$ & & & & & & & \\
\hline CONSTANT & & $\begin{array}{l}-0.806 \\
(9.86)^{* * *}\end{array}$ & $\begin{array}{c}-1.165 \\
(13.47)^{* * *}\end{array}$ & $\begin{array}{l}-0.115 \\
(1.24)\end{array}$ & $\begin{array}{l}-0.629 \\
(5.97)^{* * *}\end{array}$ & $\begin{array}{l}-1.158 \\
(4.67)^{* * *}\end{array}$ & $\begin{array}{l}-1.278 \\
(5.51)^{* * *}\end{array}$ & $\begin{array}{l}-1.121 \\
(5.31)^{* * *}\end{array}$ & $\begin{array}{l}-1.301 \\
(5.82)^{* * *}\end{array}$ \\
\hline BIG4\&2NDTIER & $(-)$ & $\begin{array}{l}-0.036 \\
(2.80)^{* * * *}\end{array}$ & $\begin{array}{l}-0.038 \\
(2.71)^{* * *}\end{array}$ & $\begin{array}{l}-0.049 \\
(3.34)^{* * * *}\end{array}$ & $\begin{array}{l}-0.052 \\
(3.10) * * *\end{array}$ & & & & \\
\hline 2NDTIER & $(-)$ & & & & & $\begin{array}{l}-0.066 \\
(2.07)^{* * *}\end{array}$ & $\begin{array}{l}-0.046 \\
(1.69)^{*}\end{array}$ & $\begin{array}{l}0.014 \\
(0.48)\end{array}$ & $\begin{array}{l}-0.038 \\
(1.34)\end{array}$ \\
\hline SIZE & $(+)$ & $\begin{array}{c}0.049 \\
(12.41)^{* * *}\end{array}$ & $\begin{array}{c}0.066 \\
(15.56)^{* * *}\end{array}$ & $\begin{array}{l}0.025 \\
(5.86)^{* * *}\end{array}$ & $\begin{array}{l}0.047 \\
(9.39)^{* * *}\end{array}$ & $\begin{array}{l}0.062 \\
(5.18)^{* * *}\end{array}$ & $\begin{array}{l}0.075 \\
(6.39)^{* * *}\end{array}$ & $\begin{array}{l}0.062 \\
(6.06)^{* * *}\end{array}$ & $\begin{array}{l}0.081 \\
(6.75)^{* * *}\end{array}$ \\
\hline ROA & $(-)$ & $\begin{array}{l}-0.764 \\
(9.13)^{* * *}\end{array}$ & $\begin{array}{l}-0.942 \\
(8.16)^{* * * *}\end{array}$ & $\begin{array}{l}-1.089 \\
(11.71)^{* * *}\end{array}$ & $\begin{array}{c}-1.411 \\
(10.27)^{* * *}\end{array}$ & $\begin{array}{l}-0.610 \\
(3.02)^{* * *}\end{array}$ & $\begin{array}{l}-0.881 \\
(3.81)^{* * *}\end{array}$ & $\begin{array}{l}-0.913 \\
(4.59)^{* * *}\end{array}$ & $\begin{array}{l}-1.306 \\
(4.83)^{* * *}\end{array}$ \\
\hline INDLTMDEQ & $(+)$ & $\begin{array}{r}0.027 \\
(0.31)\end{array}$ & & & & $\begin{array}{l}0.616 \\
(2.98)^{* * *}\end{array}$ & & & \\
\hline INDLTDEQ & $(+)$ & & $\begin{array}{r}0.109 \\
(1.52)\end{array}$ & & & & $\begin{array}{l}0.088 \\
(0.63)\end{array}$ & & \\
\hline INDTDMEQ & $(+)$ & & & $\begin{array}{l}0.200 \\
(2.68)^{* * *}\end{array}$ & & & & $\begin{array}{l}0.538 \\
(2.98)^{* * *}\end{array}$ & \\
\hline INDTDEQ & $(+)$ & & & & $\begin{array}{l}0.247 \\
(3.11)^{* * *}\end{array}$ & & & & $\begin{array}{c}0.283 \\
(1.55)\end{array}$ \\
\hline MTB & $( \pm)$ & $\begin{array}{l}-0.030 \\
(5.95)^{* * *}\end{array}$ & $\begin{array}{l}0.005 \\
(0.85)\end{array}$ & $\begin{array}{l}-0.044 \\
(7.71)^{* * *}\end{array}$ & $\begin{array}{l}0.003 \\
(0.34)\end{array}$ & $\begin{array}{l}-0.043 \\
(2.17)^{* *}\end{array}$ & $\begin{array}{c}0.001 \\
(0.06)\end{array}$ & $\begin{array}{l}-0.069 \\
(2.74)^{* * *}\end{array}$ & $\begin{array}{l}-0.036 \\
(1.41)\end{array}$ \\
\hline RET & $(-)$ & $\begin{array}{l}-0.022 \\
(2.39)^{* *}\end{array}$ & $\begin{array}{l}0.014 \\
(1.28)\end{array}$ & $\begin{array}{l}-0.020 \\
(1.80)^{*}\end{array}$ & $\begin{array}{r}0.007 \\
(0.50)\end{array}$ & $\begin{array}{l}-0.014 \\
(0.62)\end{array}$ & $\begin{array}{c}0.029 \\
(1.23)\end{array}$ & $\begin{array}{l}-0.014 \\
(0.66)\end{array}$ & $\begin{array}{l}0.035 \\
(1.22)\end{array}$ \\
\hline PPE & $(+)$ & $\begin{array}{l}0.197 \\
(6.19) * * *\end{array}$ & $\begin{array}{l}0.176 \\
(4.94)^{* * *}\end{array}$ & $\begin{array}{l}0.056 \\
(1.60)\end{array}$ & $\begin{array}{l}-0.051 \\
(1.23)\end{array}$ & $\begin{array}{l}0.223 \\
(3.41)^{* * *}\end{array}$ & $\begin{array}{c}0.132 \\
(1.99)^{* *}\end{array}$ & $\begin{array}{r}0.091 \\
(1.43)\end{array}$ & $\begin{array}{l}-0.046 \\
(0.70)\end{array}$ \\
\hline DEBTAX & $(+)$ & $\begin{array}{l}-0.105 \\
(2.93)^{* * *}\end{array}$ & $\begin{array}{l}-0.103 \\
(2.93)^{* * *}\end{array}$ & $\begin{array}{l}-0.075 \\
(2.19)^{* *}\end{array}$ & $\begin{array}{l}-0.099 \\
(2.73)^{* * *}\end{array}$ & $\begin{array}{l}-0.129 \\
(1.52)\end{array}$ & $\begin{array}{l}-0.294 \\
(3.96)^{* * *}\end{array}$ & $\begin{array}{r}0.001 \\
(0.01)\end{array}$ & $\begin{array}{l}-0.142 \\
(1.94)^{*}\end{array}$ \\
\hline NDEBTAX & $( \pm)$ & $\begin{array}{l}0.784 \\
(2.64)^{* * *}\end{array}$ & $\begin{array}{c}0.586 \\
(1.65)^{*}\end{array}$ & $\begin{array}{r}0.125 \\
(0.42)\end{array}$ & $\begin{array}{l}1.181 \\
(3.13)^{* * *}\end{array}$ & $\begin{array}{l}2.235 \\
(2.37)^{* *}\end{array}$ & $\begin{array}{l}1.664 \\
(1.60)\end{array}$ & $\begin{array}{l}2.390 \\
(3.18)^{* * *}\end{array}$ & $\begin{array}{l}2.800 \\
(3.18)^{* * *}\end{array}$ \\
\hline SDROA & $(-)$ & $\begin{array}{c}0.191 \\
(1.43)\end{array}$ & $\begin{array}{l}0.202 \\
(1.29)\end{array}$ & $\begin{array}{r}0.091 \\
(0.58)\end{array}$ & $\begin{array}{l}0.247 \\
(1.16)\end{array}$ & $\begin{array}{l}-0.036 \\
(0.14)\end{array}$ & $\begin{array}{l}-0.643 \\
(2.02)^{* *}\end{array}$ & $\begin{array}{l}-0.302 \\
(1.14)\end{array}$ & $\begin{array}{l}-0.350 \\
(1.02)\end{array}$ \\
\hline Time dummies & & Yes & Yes & Yes & Yes & Yes & Yes & Yes & Yes \\
\hline
\end{tabular}




\begin{tabular}{|c|c|c|c|c|c|c|c|c|}
\hline $\mathrm{R} 2$ & 0.36 & 0.33 & 0.34 & 0.29 & 0.38 & 0.39 & 0.37 & 0.37 \\
\hline $\mathrm{N}$ & 1,319 & 1,337 & 1,315 & 1,330 & 266 & 286 & 280 & 284 \\
\hline
\end{tabular}

For variable definitions: see Table 1 .

$*, * *, * *$ denote statistical significance at $10 \%, 5 \%$ and $1 \%$ level respectively 
Table 7C Entropy balancing Big4 and second-tier as one category

\begin{tabular}{|c|c|c|c|c|c|c|c|c|c|}
\hline & & \multicolumn{4}{|c|}{ BIG4\&2NDTIER } & \multicolumn{4}{|c|}{ 2NDTIER ONLY } \\
\hline & & LTDMEQ & LTDEQ & TDMEQ & TDEQ & LTDMEQ & LTDEQ & TDMEQ & TDEQ \\
\hline CONSTANT & & $\begin{array}{l}-1.046 \\
(8.22)^{* * *}\end{array}$ & $\begin{array}{l}-1.367 \\
(7.92)^{* * *}\end{array}$ & $\begin{array}{l}-0.367 \\
(2.80)^{* * *}\end{array}$ & $\begin{array}{l}-0.816 \\
(5.09)^{* * *}\end{array}$ & $\begin{array}{l}-1.474 \\
(8.99)^{* * *}\end{array}$ & $\begin{array}{l}-1.578 \\
(8.07)^{* * *}\end{array}$ & $\begin{array}{l}-1.013 \\
(5.94)^{* * *}\end{array}$ & $\begin{array}{l}-1.051 \\
(5.31)^{* * *}\end{array}$ \\
\hline BIG4\&2NDTIER & $(-)$ & $\begin{array}{l}-0.052 \\
(3.30)^{* * *}\end{array}$ & $\begin{array}{l}-0.039 \\
(2.07)^{* *}\end{array}$ & $\begin{array}{l}-0.044 \\
(2.69)^{* * *}\end{array}$ & $\begin{array}{l}-0.055 \\
(2.92)^{* * *}\end{array}$ & & & & \\
\hline 2NDTIER & $(-)$ & & & & & -0.031 & -0.017 & -0.014 & -0.034 \\
\hline & & & & & & (1.63) & $(0.91)$ & $(0.66)$ & (1.57) \\
\hline SIZE & $(+)$ & 0.061 & 0.078 & 0.036 & 0.060 & 0.076 & 0.085 & 0.059 & 0.066 \\
\hline & & $(9.54)^{* * *}$ & $(8.75)^{* * *}$ & $(5.86)^{* * *}$ & $(7.15)^{* * *}$ & $(9.21)^{* * *}$ & $(8.30)^{* * *}$ & $(7.25)^{* * *}$ & $(6.25)^{* * *}$ \\
\hline ROA & $(-)$ & $\begin{array}{l}-0.837 \\
(921) * * *\end{array}$ & -0.948 & -1.152 & -1.487 & -0.698 & -0.820 & -0.944 & -1.526 \\
\hline INDLTMDEQ & $(+)$ & $\begin{array}{l}(9.21)^{* * *} \\
0.124 \\
(1.22)\end{array}$ & $(7.00)^{* * *}$ & & & $\begin{array}{l}(4.79)^{* * *} \\
0.507 \\
(4.31)^{* * *}\end{array}$ & & & \\
\hline INDLTDEQ & $(+)$ & & $\begin{array}{r}0.057 \\
(0.53)\end{array}$ & & & & $\begin{array}{c}0.180 \\
(1.61)\end{array}$ & & \\
\hline INDTDMEQ & $(+)$ & & & $\begin{array}{l}0.187 \\
(2.00)^{* *}\end{array}$ & & & & $\begin{array}{l}0.527 \\
(4.02)^{* * *}\end{array}$ & \\
\hline INDTDEQ & $(+)$ & & & & $\begin{array}{r}0.149 \\
(1.51)\end{array}$ & & & & $\begin{array}{l}0.355 \\
(2.73)^{* * *}\end{array}$ \\
\hline МТВ & $( \pm)$ & $\begin{array}{l}-0.023 \\
(4.31)^{* * *}\end{array}$ & $\begin{array}{l}-0.005 \\
(0.84)\end{array}$ & $\begin{array}{l}-0.036 \\
(6.22)^{* * *}\end{array}$ & $\begin{array}{l}-0.001 \\
(0.21)\end{array}$ & $\begin{array}{l}-0.053 \\
(4.20)^{* * *}\end{array}$ & $\begin{array}{l}-0.020 \\
(1.30)\end{array}$ & $\begin{array}{l}-0.075 \\
(4.38)^{* * *}\end{array}$ & $\begin{array}{l}-0.005 \\
(0.27)\end{array}$ \\
\hline RET & $(-)$ & $\begin{array}{l}-0.006 \\
(0.43)\end{array}$ & $\begin{array}{c}0.008 \\
(0.57)\end{array}$ & $\begin{array}{l}-0.012 \\
(0.80)\end{array}$ & $\begin{array}{c}0.002 \\
(0.11)\end{array}$ & $\begin{array}{l}-0.005 \\
(0.36)\end{array}$ & $\begin{array}{c}0.013 \\
(0.75)\end{array}$ & $\begin{array}{l}-0.004 \\
(0.24)\end{array}$ & $\begin{array}{c}0.024 \\
(1.12)\end{array}$ \\
\hline DEBTAX & $(+)$ & $\begin{array}{l}-0.118 \\
(2.07)^{* *}\end{array}$ & $\begin{array}{l}-0.118 \\
(1.62)\end{array}$ & $\begin{array}{l}-0.097 \\
(1.92)^{*}\end{array}$ & $\begin{array}{l}-0.127 \\
(1.85)^{*}\end{array}$ & $\begin{array}{l}-0.090 \\
(1.45)\end{array}$ & $\begin{array}{l}-0.206 \\
(3.54)^{* * *}\end{array}$ & $\begin{array}{c}0.047 \\
(0.75)\end{array}$ & $\begin{array}{l}-0.097 \\
(1.56)\end{array}$ \\
\hline NDEBTAX & $( \pm)$ & $\begin{array}{c}0.596 \\
(1.73)^{*}\end{array}$ & $\begin{array}{c}0.277 \\
(0.58)\end{array}$ & $\begin{array}{c}0.174 \\
(0.51)\end{array}$ & $\begin{array}{c}0.688 \\
(1.31)\end{array}$ & $\begin{array}{l}2.490 \\
(3.55)^{* * *}\end{array}$ & $\begin{array}{l}2.282 \\
(2.92)^{* * *}\end{array}$ & $\begin{array}{l}2.143 \\
(3.43)^{* * *}\end{array}$ & $\begin{array}{l}2.284 \\
(2.89)^{* * *}\end{array}$ \\
\hline SDROA & $(-)$ & 0.444 & 0.530 & 0.350 & 0.707 & -0.007 & -0.487 & -0.444 & -0.634 \\
\hline
\end{tabular}




\begin{tabular}{|c|c|c|c|c|c|c|c|c|}
\hline & $(2.78)^{* * *}$ & $(2.90)^{* * *}$ & $(1.86)^{*}$ & $(3.26)^{* * *}$ & $(0.03)$ & $(1.76)^{*}$ & $(1.78)^{*}$ & $(2.23)^{* *}$ \\
\hline Time dummies & Yes & Yes & Yes & Yes & Yes & Yes & Yes & Yes \\
\hline $\mathrm{R} 2$ & 0.44 & 0.39 & 0.41 & 0.39 & 0.43 & 0.40 & 0.37 & 0.35 \\
\hline $\mathrm{N}$ & 1,977 & 1,977 & 1,977 & 1,977 & 1,214 & 1,214 & 1,214 & 1,214 \\
\hline
\end{tabular}

$*, * *, * * *$ denote statistical significance at $10 \%, 5 \%$ and $1 \%$ level respectively 
Table 8A: Two-way clustered OLS with interaction effect on Big4

\begin{tabular}{|c|c|c|c|c|c|}
\hline & & LTDMEQ & LTDEQ & TDMEQ & TDEQ \\
\hline CONSTANT & & $\begin{array}{l}-1.037 \\
(6.34)^{* * *}\end{array}$ & $\begin{array}{l}-1.192 \\
(6.16)^{* * *}\end{array}$ & $\begin{array}{l}-0.756 \\
(4.52)^{* * *}\end{array}$ & $\begin{array}{l}-1.114 \\
(4.91)^{* * * *}\end{array}$ \\
\hline BIG4 & $(-)$ & $\begin{array}{c}0.327 \\
(1.31)\end{array}$ & $\begin{array}{c}0.327 \\
(1.34)\end{array}$ & $\begin{array}{l}0.827 \\
(2.52)^{* *}\end{array}$ & $\begin{array}{l}0.799 \\
(2.48)^{* * *}\end{array}$ \\
\hline SIZE & $(+)$ & $\begin{array}{c}0.061 \\
(7.41)^{* * *}\end{array}$ & $\begin{array}{l}0.068 \\
(6.89)^{* * *}\end{array}$ & $\begin{array}{l}0.052 \\
(6.42)^{* * *}\end{array}$ & $\begin{array}{l}0.066 \\
(6.04)^{* * *}\end{array}$ \\
\hline SIZE*BIG4 & $(?)$ & $\begin{array}{l}-0.019 \\
(1.64)\end{array}$ & $\begin{array}{l}-0.018 \\
(1.55)\end{array}$ & $\begin{array}{l}-0.041 \\
(2.76)^{* * *}\end{array}$ & $\begin{array}{l}-0.039 \\
(2.67)^{* * *}\end{array}$ \\
\hline ROA & $(-)$ & $\begin{array}{l}-0.624 \\
(6.36)^{* * *}\end{array}$ & $\begin{array}{l}-0.655 \\
(5.31)^{* * *}\end{array}$ & $\begin{array}{l}-0.789 \\
(6.68)^{* * *}\end{array}$ & $\begin{array}{l}-1.131 \\
(6.47)^{* * * *}\end{array}$ \\
\hline INDLTMDEQ & $(+)$ & $\begin{array}{r}0.005 \\
(0.08)\end{array}$ & & & \\
\hline INDLTDEQ & $(+)$ & & $\begin{array}{c}0.239 \\
(2.56)^{* *}\end{array}$ & & \\
\hline INDTDMEQ & $(+)$ & & & $\begin{array}{c}0.055 \\
(0.36)\end{array}$ & \\
\hline INDTDEQ & $(+)$ & & & & $\begin{array}{c}0.413 \\
(2.48)^{* *}\end{array}$ \\
\hline MTB & $( \pm)$ & $\begin{array}{l}-0.020 \\
(3.36)^{* * *}\end{array}$ & $\begin{array}{l}-0.005 \\
(0.67)\end{array}$ & $\begin{array}{l}-0.034 \\
(4.88)^{* * *}\end{array}$ & $\begin{array}{r}0.005 \\
(0.50)\end{array}$ \\
\hline RET & $(-)$ & $\begin{array}{l}-0.028 \\
(3.38)^{* * *}\end{array}$ & $\begin{array}{c}0.001 \\
(0.19)\end{array}$ & $\begin{array}{l}-0.032 \\
(3.98)^{* * *}\end{array}$ & $\begin{array}{l}-0.004 \\
(0.43)\end{array}$ \\
\hline PPE & $(+)$ & $\begin{array}{c}0.199 \\
(4.57)^{* * *}\end{array}$ & $\begin{array}{l}0.184 \\
(4.10)^{* * *}\end{array}$ & $\begin{array}{c}0.094 \\
(1.89)^{*}\end{array}$ & $\begin{array}{r}0.010 \\
(0.17)\end{array}$ \\
\hline DEBTAX & $(+)$ & $\begin{array}{l}-0.092 \\
(3.04)^{* * *}\end{array}$ & $\begin{array}{l}-0.062 \\
(1.82)^{*}\end{array}$ & $\begin{array}{l}-0.067 \\
(1.44)\end{array}$ & $\begin{array}{l}-0.058 \\
(1.31)\end{array}$ \\
\hline NDEBTAX & $( \pm)$ & $\begin{array}{c}0.895 \\
(1.75)^{*}\end{array}$ & $\begin{array}{c}0.684 \\
(1.32)\end{array}$ & $\begin{array}{c}0.715 \\
(1.33)\end{array}$ & $\begin{array}{c}1.096 \\
(1.66)^{*}\end{array}$ \\
\hline SDROA & $(-)$ & $\begin{array}{l}0.040 \\
(0.31)\end{array}$ & $\begin{array}{l}-0.024 \\
(0.17)\end{array}$ & $\begin{array}{l}-0.121 \\
(0.81)\end{array}$ & $\begin{array}{c}0.078 \\
(0.31)\end{array}$ \\
\hline Time dummies & & Yes & Yes & Yes & Yes \\
\hline $\mathrm{R} 2$ & & 0.34 & 0.28 & 0.31 & 0.23 \\
\hline $\mathrm{N}$ & & 1,977 & 1,977 & 1,977 & 1,977 \\
\hline
\end{tabular}

For variable definitions: see Table 1.

$*, * *, * * *$ denote statistical significance at $10 \%, 5 \%$ and $1 \%$ level respectively 
Table 8B Propensity score matching with interaction effect on Big4

\begin{tabular}{|c|c|c|c|c|c|}
\hline & & LTDMEQ & LTDEQ & TDMEQ & TDEQ \\
\hline CONSTANT & & $\begin{array}{c}-1.668 \\
(10.82)^{* * *}\end{array}$ & $\begin{array}{l}-1.593 \\
(8.35)^{* * *}\end{array}$ & $\begin{array}{l}-0.793 \\
(4.59)^{* * *}\end{array}$ & $\begin{array}{l}-0.954 \\
(3.69)^{* * *}\end{array}$ \\
\hline BIG4 & $(-)$ & $\begin{array}{l}0.950 \\
(5.09) * * *\end{array}$ & $\begin{array}{l}0.620 \\
(2.85) * * *\end{array}$ & $\begin{array}{l}0.968 \\
(4.62) * * *\end{array}$ & $\begin{array}{c}0.607 \\
(1.95)^{*}\end{array}$ \\
\hline SIZE & $(+)$ & $\begin{array}{c}0.088 \\
(12.43)^{* * *}\end{array}$ & $\begin{array}{l}0.083 \\
(9.52)^{* * *}\end{array}$ & $\begin{array}{l}0.057 \\
(7.63)^{* * *}\end{array}$ & $\begin{array}{l}0.061 \\
(5.05)^{* * *}\end{array}$ \\
\hline SIZE*BIG4 & (?) & $\begin{array}{l}-0.046 \\
(5.33)^{* * * *}\end{array}$ & $\begin{array}{l}-0.030 \\
(2.99)^{* * *}\end{array}$ & $\begin{array}{l}-0.047 \\
(4.92) * * *\end{array}$ & $\begin{array}{l}-0.030 \\
(2.11)^{* *}\end{array}$ \\
\hline $\mathrm{ROA}$ & $(-)$ & $\begin{array}{l}-0.831 \\
(9.36)^{* * *}\end{array}$ & $\begin{array}{l}-0.880 \\
(7.09)^{* * *}\end{array}$ & $\begin{array}{c}-1.052 \\
(10.42)^{* * *}\end{array}$ & $\begin{array}{l}-1.401 \\
(9.18)^{* * *}\end{array}$ \\
\hline INDLTMDEQ & $(+)$ & $\begin{array}{r}0.052 \\
(0.58)\end{array}$ & & & \\
\hline INDLTDEQ & $(+)$ & & $\begin{array}{l}0.224 \\
(2.93)^{* * *}\end{array}$ & & \\
\hline INDTDMEQ & $(+)$ & & & $\begin{array}{c}0.076 \\
(0.86)\end{array}$ & \\
\hline INDTDEQ & $(+)$ & & & & $\begin{array}{l}0.325 \\
(3.53)^{* * *}\end{array}$ \\
\hline MTB & $( \pm)$ & $\begin{array}{l}-0.021 \\
(4.08) * * *\end{array}$ & $\begin{array}{r}0.007 \\
(0.98)\end{array}$ & $\begin{array}{l}-0.047 \\
(7.98)^{* * *}\end{array}$ & $\begin{array}{r}0.013 \\
(1.27)\end{array}$ \\
\hline RET & $(-)$ & $\begin{array}{l}-0.023 \\
(2.32)^{* *}\end{array}$ & $\begin{array}{l}-0.002 \\
(0.18)\end{array}$ & $\begin{array}{l}-0.014 \\
(1.17)\end{array}$ & $\begin{array}{r}0.002 \\
(0.11)\end{array}$ \\
\hline PPE & $(+)$ & $\begin{array}{c}0.239 \\
(6.65)^{* * *}\end{array}$ & $\begin{array}{c}0.184 \\
(4.75)^{* * *}\end{array}$ & $\begin{array}{c}0.075 \\
(2.00)^{* *}\end{array}$ & $\begin{array}{l}-0.088 \\
(1.97)^{* *}\end{array}$ \\
\hline DEBTAX & $(+)$ & $\begin{array}{l}-0.083 \\
(2.32)^{* *}\end{array}$ & $\begin{array}{l}-0.095 \\
(2.57)^{* *}\end{array}$ & $\begin{array}{l}-0.077 \\
(2.12)^{* *}\end{array}$ & $\begin{array}{l}-0.089 \\
(2.42)^{* *}\end{array}$ \\
\hline NDEBTAX & $( \pm)$ & $\begin{array}{c}0.131 \\
(0.49)\end{array}$ & $\begin{array}{l}0.353 \\
(0.97)\end{array}$ & $\begin{array}{l}0.003 \\
(0.01)\end{array}$ & $\begin{array}{c}0.747 \\
(1.98)^{* *}\end{array}$ \\
\hline SDROA & $(-)$ & $\begin{array}{c}0.381 \\
(2.65)^{* * *}\end{array}$ & $\begin{array}{c}0.298 \\
(1.49)\end{array}$ & $\begin{array}{c}0.166 \\
(0.85)\end{array}$ & $\begin{array}{c}0.630 \\
(2.27)^{* *}\end{array}$ \\
\hline Time dummies & & Yes & Yes & Yes & Yes \\
\hline $\mathrm{R} 2$ & & 0.41 & 0.32 & 0.38 & 0.29 \\
\hline $\mathrm{N}$ & & 1,072 & 1,071 & 1,079 & 1,053 \\
\hline
\end{tabular}

For variable definitions: see Table 1

$*, * *, * * *$ denote statistical significance at $10 \%, 5 \%$ and $1 \%$ level respectively 
Table 8C Entropy balancing with interaction effect on Big4

\begin{tabular}{|c|c|c|c|c|c|}
\hline & & LTDMEQ & LTDEQ & TDMEQ & TDEQ \\
\hline CONSTANT & & $\begin{array}{l}-1.482 \\
(4.87)^{* * *}\end{array}$ & $\begin{array}{l}-1.957 \\
(4.77)^{* * *}\end{array}$ & $\begin{array}{l}-0.986 \\
(3.52)^{* * *}\end{array}$ & $\begin{array}{l}-1.660 \\
(4.29)^{* * *}\end{array}$ \\
\hline BIG4 & $(-)$ & $\begin{array}{l}0.734 \\
(2.31)^{* *}\end{array}$ & $\begin{array}{l}0.892 \\
(2.20)^{* *}\end{array}$ & $\begin{array}{l}0.978 \\
(3.27) * * *\end{array}$ & $\begin{array}{l}1.276 \\
(3.11)^{* * *}\end{array}$ \\
\hline SIZE & $(+)$ & $\begin{array}{l}0.079 \\
(5.53)^{* * *}\end{array}$ & $\begin{array}{l}0.103 \\
(5.31)^{* * *}\end{array}$ & $\begin{array}{l}0.058 \\
(4.45)^{* * *}\end{array}$ & $\begin{array}{l}0.092 \\
(5.04)^{* * *}\end{array}$ \\
\hline SIZE*BIG4 & (?) & $\begin{array}{l}-0.036 \\
(2.47)^{* *}\end{array}$ & $\begin{array}{l}-0.043 \\
(2.28) * *\end{array}$ & $\begin{array}{l}-0.046 \\
(3.40)^{* * *}\end{array}$ & $\begin{array}{l}-0.060 \\
(3.21)^{* * *}\end{array}$ \\
\hline $\mathrm{ROA}$ & $(-)$ & $\begin{array}{l}-0.862 \\
(7.14)^{* * *}\end{array}$ & $\begin{array}{l}-1.117 \\
(6.75)^{* * *}\end{array}$ & $\begin{array}{l}-1.069 \\
(7.92)^{* * *}\end{array}$ & $\begin{array}{l}-1.561 \\
(8.44)^{* * *}\end{array}$ \\
\hline INDLTMDEQ & $(+)$ & $\begin{array}{l}0.262 \\
(2.35)^{* *}\end{array}$ & & & \\
\hline INDLTDEQ & $(+)$ & & $\begin{array}{l}0.153 \\
(1.45)\end{array}$ & & \\
\hline INDTDMEQ & $(+)$ & & & $\begin{array}{l}0.393 \\
(3.62)^{* * *}\end{array}$ & \\
\hline INDTDEQ & $(+)$ & & & & $\begin{array}{l}0.437 \\
(3.39)^{* * *}\end{array}$ \\
\hline MTB & $( \pm)$ & $\begin{array}{l}-0.016 \\
(2.59)^{* * *}\end{array}$ & $\begin{array}{r}0.005 \\
(0.62)\end{array}$ & $\begin{array}{l}-0.030 \\
(4.57)^{* * *}\end{array}$ & $\begin{array}{r}0.007 \\
(0.75)\end{array}$ \\
\hline RET & $(-)$ & $\begin{array}{r}0.002 \\
(0.12)\end{array}$ & $\begin{array}{r}0.012 \\
(0.68)\end{array}$ & $\begin{array}{r}0.005 \\
(0.29)\end{array}$ & $\begin{array}{r}0.001 \\
(0.06)\end{array}$ \\
\hline PPE & $(+)$ & $\begin{array}{c}0.094 \\
(1.76)^{*}\end{array}$ & $\begin{array}{r}0.113 \\
(1.60)\end{array}$ & $\begin{array}{l}-0.028 \\
(0.48)\end{array}$ & $\begin{array}{l}-0.178 \\
(2.30)^{* *}\end{array}$ \\
\hline DEBTAX & $(+)$ & $\begin{array}{l}-0.099 \\
(1.75)^{*}\end{array}$ & $\begin{array}{l}-0.081 \\
(1.12)\end{array}$ & $\begin{array}{l}-0.106 \\
(2.13)^{* *}\end{array}$ & $\begin{array}{l}-0.163 \\
(2.37)^{* *}\end{array}$ \\
\hline NDEBTAX & $( \pm)$ & $\begin{array}{l}1.132 \\
(2.58)^{* * *}\end{array}$ & $\begin{array}{r}0.692 \\
(1.03)\end{array}$ & $\begin{array}{c}0.850 \\
(1.91)^{*}\end{array}$ & $\begin{array}{l}1.825 \\
(2.86)^{* * *}\end{array}$ \\
\hline SDROA & $(-)$ & $\begin{array}{c}0.336 \\
(1.61)\end{array}$ & $\begin{array}{l}0.624 \\
(2.60)^{* * *}\end{array}$ & $\begin{array}{c}0.263 \\
(1.15)\end{array}$ & $\begin{array}{c}0.657 \\
(2.25)^{* *}\end{array}$ \\
\hline Time dummies & & Yes & Yes & Yes & Yes \\
\hline $\mathrm{R} 2$ & & 0.45 & 0.44 & 0.44 & 0.45 \\
\hline $\mathrm{N}$ & & 1,977 & 1,977 & 1,977 & 1,977 \\
\hline
\end{tabular}


